J Mater Chem B Mater Biol Med. 2015 August 28; 3(32): 6676-6689. doi:10.1039/C5TB01319D.

\title{
Addition of $\mathrm{Zn}$ to the ternary Mg-Ca-Sr alloys significantly improves their antibacterial property
}

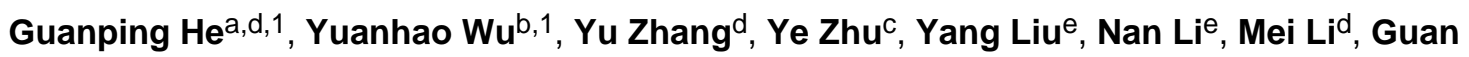

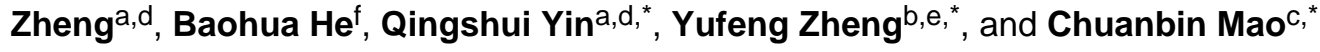 \\ aSouthern Medical University, Guangzhou 510515, China \\ ${ }^{b}$ Center for Biomedical Materials and Tissue Engineering, Academy for Advanced \\ Interdisciplinary Studies, Peking University, Beijing 100871, China \\ 'Department of Chemistry and Biochemistry, Stephenson Life Sciences Research Center, \\ University of Oklahoma, Norman, OK73019, USA \\ ${ }^{d}$ Department of Orthopedics, Guangdong Key Lab of Orthopedic Technology and Implant, \\ Guangzhou General Hospital of Guangzhou Military Command, 111 Liuhua Road, Guangzhou, \\ Guangdong 510010, China \\ eDepartment of Materials Science and Engineering, College of Engineering, Peking University, \\ Beijing 100871, China. Department of Materials Science and Engineering, College of \\ Engineering, Peking University, Beijing 100871, China \\ fDepartment of Orthopedics, China Meitan General Hospital, No.29 Xibahe South street, \\ Chaoyang District, Beijing, 100028, china
}

\section{Abstract}

\begin{abstract}
Most of the magnesium $(\mathrm{Mg})$ alloys possess excellent biocompatibility, mechanical property and biodegradability in orthopedic applications. However, these alloys may suffer from bacterial infections due to their insufficient antibacterial capability. In order to reduce the post-surgical infections, a series of biocompatible $\mathrm{Mg}-1 \mathrm{Ca}-0.5 \mathrm{Sr}-\mathrm{xZn}(\mathrm{x}=0,2,4,6)$ alloys were fabricated with the addition of antibacterial $\mathrm{Zn}$ with variable content and evaluated in terms of their biocompatibility and antibacterial property. The in vitro corrosion study showed that $\mathrm{Mg}-1 \mathrm{Ca}-0.5 \mathrm{Sr}-6 \mathrm{Zn}$ alloys exhibited a higher hydrogen evolution volume after $100 \mathrm{~h}$ immersion and resulted in a higher $\mathrm{pH}$ value of the immersion solution. Our work indicated that $\mathrm{Zn}$ containing $\mathrm{Mg}$ alloys exhibited good biocompatibility with high cell viability. The antibacterial studies reveal that the number of bacteria adhered on all of these $\mathrm{Mg}$ alloy samples diminished remarkably compared to the Ti-6Al-4V control group. We also found that the proliferation of the bacteria was inhibited by these Mg alloys extracts. Among the prepared alloys, $\mathrm{Mg}-1 \mathrm{Ca}-0.5 \mathrm{Sr}-6 \mathrm{Zn}$ alloy not only exhibited a strong antibacterial effect, but also promoted the proliferation of
\end{abstract}

\footnotetext{
*Corresponding authors: yfzheng@ @ku.edu.cn (YF Zheng), gz_yqs@126.com (QS Yin), cbmao@ ou.edu (CB Mao).

${ }^{1}$ These two authors contributed equally to this work.

Electronic Supplementary Information (ESI) available: [details of any supplementary information available should be included here]. See DOI: $10.1039 / \mathrm{x} 0 \mathrm{xx} 00000 \mathrm{x}$
} 
MC3T3-E1 osteoblasts, suggesting that it is a promising alloy with both good antibacterial property and good biocompatibility for use as an orthopedic implant.

\section{Introduction}

Nowadays, the implantation of the implants into the desired place may lead to bacterial infections on the material surface or along the bone/material interface despite total disinfection prior to the surgeries. ${ }^{1-4}$ These infections were often caused by bacteria adherence. ${ }^{2,5}$ After the bacterial proliferation periods, the infections associated with the implants can hardly be cured by traditional systemic antibiotic therapy due to the formation of biofilms ${ }^{1}$. The biofilms can also protect the bacteria against human defense system ${ }^{2}$. It was reported that the infection rate in orthopedic and trauma surgeries for open fracture could be up to about $1 \%$ and $12-53 \%$, respectively. ${ }^{2}$ Implant infections also leads to implant failure, a secondary surgery, osteomyelitis, member amputation, or even death. ${ }^{1,6-8}$ Although sterile operation and antibiotics were adopted in clinic situations, post-surgical infections are still one of the intractable problems. ${ }^{9,}{ }^{10}$ Hence, there is a pressing need in the development of biocompatible implants with antibacterial property.

$\mathrm{Mg}$ is one of the most reactive metals and, thus, susceptible to rapid dissolution, especially in chloride-containing aqueous solutions. ${ }^{11}$ Therefore, $\mathrm{Mg}$ and its alloys can degrade gradually in the body fluid environment after bone healing procedure, which can eliminate the need for a second operation for implant removal. ${ }^{12}$ The biodegradability of $\mathrm{Mg}$ and its alloys can also eliminate the complications associated with the long-standing presence of implants in the body and the impact on computed tomography (CT) as well as other imaging examinations. Furthermore, $\mathrm{Mg}$ alloys have high specific strength and a modulus that is comparable with that of human natural bones, thereby the $\mathrm{Mg}$ and its alloys would reduce the risk of stress shielding effect in orthopedic applications ${ }^{12}$. Additionally, as an essential metal element, $\mathrm{Mg}$ is rich in the human body and the degradation products from $\mathrm{Mg}$ are expected to be nontoxic to the surrounding tissue, due to the homeostatic control mechanisms. ${ }^{13}$ Once these materials degrade within the body, the degradation products are able to be metabolized and absorbed by the body. ${ }^{14,15}$

However, Mg usually exhibits a fast degradation rate before bone healing, which can lead to premature loss of the mechanical integrity and excess hydrogen evolution of the implant, resulting in the failure of the implantation ${ }^{12}$. Fortunately, the degradation behavior of $\mathrm{Mg}$ can be tailored by the alloying elements. ${ }^{16-19}$

Calcium $(\mathrm{Ca})$ is one of the most abundant metal elements in human body, and is also the major component of human bones. ${ }^{20}$ Meanwhile, Ca can increase the corrosion resistance of pure Mg. ${ }^{17}$ It is reported that strontium ( $\mathrm{Sr}$ ) has the potential to stimulate bone formation ${ }^{21}$ and $\mathrm{Sr}$ ranelate has shown to be effective for treating osteoporosis by increasing bone mineral density and bone strength. ${ }^{22-24}$ Furthermore, it has been verified that adding small amount of $\mathrm{Ca}$ and $\mathrm{Sr}$ into $\mathrm{Mg}$-based alloys can improve the mechanical properties of pure $\mathrm{Mg}$ by grain refinement mechanism. ${ }^{25,26}$ Berglund et $\mathrm{al}^{27}$ further found that low amounts of alloying elements enhanced the corrosion resistance properties, with an optimal composition of $1 \mathrm{wt}$. \% $\mathrm{Ca}$ and $0.5 \mathrm{wt} . \% \mathrm{Sr}$. The ternary alloy exhibited a higher compressive strength 
than that of binary $\mathrm{Mg}-\mathrm{Ca}$ alloys with similar Ca contents, and also showed negligible toxicity.

On the other hand, multifunctional biodegradable metals are in great need for biomedical applications. It is known that Zinc $(\mathrm{Zn})$ is an essential mineral component for hundreds of biological enzymes and transcription factors and is widely associated with the normal function or structure of more than 300 proteins. ${ }^{28,29}$ Moreover, many studies ${ }^{30-35}$ demonstrated that Zn exhibits antibacterial effect on Staphylococcus aureus (S. aureus). Thus, the addition of $\mathrm{Zn}$ in the $\mathrm{Mg}-\mathrm{Ca}-\mathrm{Sr}$ based alloys may produce a biomaterial with antibacterial property.

Herein, in this study, we want to combine the antibacterial property of $\mathrm{Zn}$ with the ternary $\mathrm{Mg}$ alloys (Mg-1.0Ca-0.5Sr) and fabricate the quaternary $\mathrm{Mg}-1 \mathrm{Ca}-0.5 \mathrm{Sr}-(2,4,6 \mathrm{wt} . \%) \mathrm{Zn}$ alloys, while the $\mathrm{Mg}-1 \mathrm{Ca}-0.5 \mathrm{Sr}$ and $\mathrm{Ti}-6 \mathrm{Al}-4 \mathrm{~V}$ alloys were selected as control. S. aureus was selected to conduct the in vitro antibacterial assays. The cytotoxicity of the alloys were also evaluated in vitro by indirect MTT assays. The antibacterial property coupled with biodegradability of the prepared Mg-Ca-Sr-Zn alloys would provide a new type of multifunctional orthopedic biomaterials.

\section{Materials and methods}

\subsection{Preparation of magnesium alloys}

$\mathrm{Mg}-\mathrm{Ca}-\mathrm{Sr}-\mathrm{Zn}$ alloy with a nominal composition of $1 \mathrm{wt}$. \% Ca, $0.5 \mathrm{wt} . \% \mathrm{Sr}$, and variable $\mathrm{Zn}$ $(0,2,4$, or 6 wt.\%) were prepared from commercial pure $\mathrm{Mg}$ (99.9\%), Ca (99.8\%), $\mathrm{Sr}$ (99.9\%) and $\mathrm{Zn}(99.9 \%)$. The raw $\mathrm{Mg}$ ingots were melt in a high purity graphite crucible under the protection of a high purity $\operatorname{Ar}(99.99 \%)$ atmosphere at about $670{ }^{\circ} \mathrm{C}$. After the addition of the alloy elements, the temperature of the melts was increased to $720^{\circ} \mathrm{C}$. After being held for about $40 \mathrm{~min}$, the melts were poured into a steel mold preheated to $250^{\circ} \mathrm{C}$. During the whole melting procedure, mechanical stirring was applied. The as-cast ingots of $\mathrm{Mg}-\mathrm{Ca}-\mathrm{Sr}-\mathrm{Zn}$ alloys were solid solution treated at $340^{\circ} \mathrm{C}$ for about $4 \mathrm{~h}$, followed by quenching in water. Finally the alloy samples were hot extruded at the temperature about $320^{\circ} \mathrm{C}$ with an extrusion speed of $2 \mathrm{~mm} / \mathrm{min}$. The disk sample with a diameter of $12 \mathrm{~mm}$ and a height of $2 \mathrm{~mm}$ were cut from the extruded ingots. Subsequently, the disk samples were abraded with up to 2000-grit $\mathrm{SiC}$ water paper and ultrasonically cleaned in acetone, absolute ethyl alcohol and deionized water for about 10min, respectively.

\subsection{Microstructure characterization}

$\mathrm{X}$-ray diffraction analysis was applied to identify the phase composition of the alloys. For microstructure analysis, the polished alloys samples were chemically etched with a 4 vol.\% nitric acid solution. The etched samples were then observed by scanning electron microscopy (SEM, Hitachi S-4800) equipped with energy dispersive spectrometry (EDS).

\subsection{Immersion tests}

Immersion tests were carried out in the Hank's solution with an area/volume ratio of 1 $\mathrm{cm}^{2} / 20 \mathrm{ml}$ for about 10 days and the temperature was kept at $37^{\circ} \mathrm{C}$ using water bath. During 
the whole immersion periods, the $\mathrm{pH}$ value of the immersion solution was detected everyday using a pH meter (Sartorius, PB-10). After the indicated immersion periods, all the alloy samples were carried out of the solution and washed with distilled water for 3 times and then air dried. The surface morphology and the composition of the corrosion products on the sample surfaces were characterized by SEM (Hitachi S-4800).

\subsection{Hydrogen evolution tests}

A self-made set was used to determine the hydrogen evolution of the alloys in Hank's solution. Briefly, three alloy samples were soaked in the beaker containing Hank's solution with an area/volume ration of $1 \mathrm{~cm}^{2} / 40 \mathrm{ml}$. The solution was kept at $37^{\circ} \mathrm{C}$ with water bath. A reversed funnel was placed over the samples, and then an acid burette filled with Hank's solution was mounted over the funnel to collect the hydrogen released from the sample surface. The hydrogen evolution volume was detected and the hydrogen evolution rate was calculated according to a reported method. ${ }^{36}$

\subsection{Magnesium alloys extracts preparation}

The extracts of $\mathrm{Mg}-\mathrm{Ca}-\mathrm{Sr}-\mathrm{Zn}$ alloys for the antibacterial assays were prepared as follows. Before the immersion procedure, all the alloy samples were sterilized in $70 \%$ ethanol for 30 min and rinsed with a $0.85 \% \mathrm{NaCl}$ solution. Then the alloy samples were immersed in phosphate buffered saline (PBS) solution with an extraction ratio of $1.25 \mathrm{~cm}^{2} / \mathrm{ml}$ and incubated at $37^{\circ} \mathrm{C}$ in a humidified atmosphere of $5 \% \mathrm{CO}_{2}$ for $72 \mathrm{~h}$, and then the extracts were centrifuged at $3000 \mathrm{rpm}$ for $5 \mathrm{~min}$ to remove the alloys particulates, the supernatants were then collected and stored at $4^{\circ} \mathrm{C}$ prior to the experiments. Finally, the ion concentration of $\mathrm{Mg}, \mathrm{Ca} \mathrm{Sr}$ and $\mathrm{Zn}$ in the extracts were detected by Inductively Coupled Plasma Atomic Emission Spectroscopy (ICP-AES). The pH value and osmolality of the extracts were measured with pH meter (Sartorius, PB-10) and Micro-Sample Osmometer (Fiske 210), respectively. Three replicates were measured for each extract. a-MEM extracts for cytotoxicity tests were prepared in a similar way by changing the PBS solution into a-MEM medium.

\subsection{Antibacterial properties}

2.6.1 Bacterial culture-As one of the most common bacteria that cause orthopedic implants infections, ${ }^{37}$ S. aureus (ATCC 25922) was used as a model bacterium to determine the antibacterial property of the alloys in vitro. S. aureus was aerobically cultured in a $37^{\circ} \mathrm{C}$ shaker incubator at $220 \mathrm{rpm}$ for $16 \mathrm{~h}$ in $5 \mathrm{~mL}$ of Luria-Bertani (LB) medium containing 10 $\mathrm{g} / \mathrm{L}$ peptone, $10 \mathrm{~g} / \mathrm{L} \mathrm{NaCl}$, and $5.0 \mathrm{~g} / \mathrm{L}$ beef extract. The density of the bacteria cultured in the medium was quantified by absorption spectroscopy at the wavelength about $600 \mathrm{~nm}$ (OD600) after performing colony counts on different concentration bacterial suspensions. OD600 was converted to colony forming units (CFU) as follows: OD600 $=0.1$ contained $\sim 10^{8} \mathrm{CFU}$. Serial dilution of the bacteria was performed in LB medium to achieve a final bacterial cell suspension of $1 \times 10^{6}$ and $1 \times 10^{7} \mathrm{CFU} / \mathrm{ml}$, respectively.

2.6.2 Indirect bactericidal assay—For each test, $100 \mu \mathrm{l}$ bacterial suspension and $100 \mu \mathrm{l}$ alloys extracts were added to $800 \mu \mathrm{l}$ PBS. The control wells contained only $100 \mu \mathrm{l}$ bacterial suspension and $900 \mu \mathrm{l}$ PBS without the addition of alloy extracts. Microplates were then 
incubated aerobically at $37{ }^{\circ} \mathrm{C}$ in a humidified atmosphere with $5 \% \mathrm{CO}_{2}$ in an incubator for $24 \mathrm{~h}$. Then, aliquots of $100 \mu \mathrm{l}$ were plated in duplicate on the agar plates. CFU were determined on the plates after incubation for another $24 \mathrm{~h}$. The assays were carried out in duplicate.

In order to determine the antibacterial potency of $\mathrm{Mg}$ alloys with different extract time, alloy extracts were prepared by immersing the alloys in PBS for 1, 6, 12, 24, 48, 72 and $96 \mathrm{~h}$ with an area/volume ration of $1.25 \mathrm{~cm}^{2} / \mathrm{ml}$. Antibacterial curves of the alloys extracts were obtained by incubating $1 \mathrm{ml}$ bacterial suspension with the extracts, which were extracted at the indicated time, for $24 \mathrm{~h}$ at a bacterial concentration of $10^{6} \mathrm{CFU} / \mathrm{ml}$. Then, viable bacteria were quantified by plating $100 \mu \mathrm{l}$ of diluted aliquots in duplicate on the agar plates. CFU were determined on the plates after incubation for $24 \mathrm{~h}$ at $37^{\circ} \mathrm{C}$ in a humidified atmosphere with $5 \% \mathrm{CO}_{2}$. The assays were carried out in duplicate.

2.6.3 Direct bactericidal assay-To evaluate the direct antibacterial property of the alloys, $1 \mathrm{ml}$ of the bacterial suspension at a concentration of $10^{7} \mathrm{CFU} / \mathrm{ml}$ was added to each experimental sample in 24-well plates. Then the plates were incubated at $37^{\circ} \mathrm{C}$ in a humidified atmosphere with $5 \% \mathrm{CO}_{2}$ for $4 \mathrm{~h}$. After the incubation procedure, the samples were gently rinsed three times with PBS in order to eliminate the non-adherent bacteria and then transferred to new tubes containing $5 \mathrm{ml}$ of PBS. The samples in the tubes were then sonicated for $5 \mathrm{~min}$ in a $40 \mathrm{~W}$ ultrasonic bath at a nominal frequency of $43,000 \mathrm{~Hz}$ followed by vortexing for thirty seconds to remove the adherent bacteria into the PBS solutions. The viable organisms in the PBS buffers were quantified by plating serial dilutions on the LB broth agar plates. The plates were incubated for $24 \mathrm{~h}$ at $37{ }^{\circ} \mathrm{C}$ in a humidified atmosphere with $5 \% \mathrm{CO} 2$, and the colony-forming units were counted with naked eyes.

To further evaluate the impact of alloys on $S$. aureus viability, live/dead staining assay was applied. Briefly, $1 \mathrm{ml}$ of the bacterial suspension with a concentration of $10^{7} \mathrm{CFU} / \mathrm{ml} S$. aureus was added to each experimental sample in 24-well plates and then incubated at $37{ }^{\circ} \mathrm{C}$ for $30 \mathrm{~min}$. The suspended and non-adhered bacteria were then gently removed by rinsing in a PBS solution. Subsequently, a LIVE/DEAD BacLight Viability Kit (Invitrogen) was used to stain the bacteria. Images of the bacteria were obtained with a fluorescence microscope (Olympus, Bx51) with a green filter (excitation/emission, $420-480 \mathrm{~nm} / 520-580 \mathrm{~nm}$ ) and a red filter (excitation/emission, 480-550 nm/590-800 nm).

2.6.4 Bacterial Adhesion assay-To evaluate the anti-adherence property of the alloys, $1 \mathrm{ml}$ of the bacterial suspension with a concentration of $10^{7} \mathrm{CFU} / \mathrm{ml}$ S. aureus was added to each experimental sample in 24 well plates at $37^{\circ} \mathrm{C}$. After incubated for $4 \mathrm{~h}$, the samples were taken out of the culture mediums and fixed with $3 \%$ glutaredehyde for $5 \mathrm{~h}$. Then, the fixed alloy samples were rinsed in PBS three times, and each were $10 \mathrm{~min}$. All the samples were then dehydrated sequentially in a series of ethanol water mixture $(50 \%, 70 \%, 95 \%$ and $100 \%$ ) for 10 min each, the dehydration process in $100 \%$ ethanol was repeated twice. Finally, the surfaces were air dried in a fume hood. The adhesion and spreading of the bacterial on Mg alloys and Ti-6Al-4V (control) samples were observed by SEM. 
For DAPI staining, after incubated with the alloys samples for 30, 60 and $90 \mathrm{~min}$, S. aureus was counterstained with DAPI (Roche, Germany). These immunostained bacteria were visualized under the fluorescent microscope (Olympus, Bx51) and the number of adhesion bacteria was counted in five random fields.

\subsection{Proliferation and cytotoxicity tests}

2.7.1 Cell culture-MC3T3-E1 pre-osteoblastic cells were adopted to evaluate the proliferation and cytotoxicity of the $\mathrm{Mg}$ alloys. The cells were cultured at $37^{\circ} \mathrm{C}$ in a humidified atmosphere of $5 \% \mathrm{CO}_{2}$ in $25-\mathrm{cm}^{2}$ tissue culture flasks. The cell culture medium used was modified Eagle's minimum essential medium (a-MEM, Hyclone, USA) with 4.5 $\mathrm{g} / \mathrm{l}$ glucose, $10 \%$ fetal calf serum (Hyclone), $10 \mu \mathrm{g} / \mathrm{ml}$ ascorbic acid, $50 \mathrm{U} / \mathrm{ml}$ penicillin, and $50 \mathrm{U} / \mathrm{ml}$ streptomycin.

2.7.2 Cell viability assay-Cell proliferation testing was carried out with indirect extract assay. The cells were cultured in a 96-well tissue culture plate at a density of $2 \times 10^{4}$ cells $/ \mathrm{ml}$ for 1 day to allow attachment. The medium was then replaced by $100 \mu$ of extracts supplemented with $10 \%$ FBS. During the culture periods, the culture media were changed every two days. After incubated for 2, 4 and 6 days, the extracts were withdrawn and $200 \mu \mathrm{l}$ of (3-(4,5-dimethylthiazol-2-yl)-2,5-diphenyltetrazolium bromide (MTT) was added to each well. After incubation for $4 \mathrm{~h}, 150 \mu \mathrm{l}$ dimethyl sulfoxide (DMSO) was added. Optical density (OD) values from the cells in the wells were measured at $490 \mathrm{~nm}$ by a microplate reader (Biocell-2010, Austria ). Data are presented as the mean \pm standard deviation.

For the Live/Dead staining, the cells were cultured on a 24-well tissue culture plate at a density of $2 \times 10^{4}$ cells $/ \mathrm{ml}$ for 1 day to allow attachment. The medium was then replaced by $500 \mu \mathrm{l}$ of extracts supplemented with $10 \%$ FBS. The culture media were replaced every two days. After incubated in 24 -well plate at $37^{\circ} \mathrm{C}$ in a humidified atmosphere with $5 \% \mathrm{CO}_{2}$ for 6 days, the suspended and non-adhered cells were then washed out by PBS solution.

Subsequently, Live/Dead staining was applied according to the manufacturer's protocol (Sigma, USA). Briefly, $0.9 \mu \mathrm{l}$ calcien AM and $3 \mu$ ethidium homodimer-1 solutions were dissolved in $3 \mathrm{ml}$ PBS, then $100 \mu \mathrm{l}$ of the mixture PBS were added in each well of the 24well plates for 30min. Then a fluorescence microscope (Eclipse Ti-S, Nikon, Düsseldorf, Germany) was utilized to observe and calculate the viability of tested cells. Viable cells show a green fluorescence through the reaction of the acetomethoxy derivate of calcein with intracellular esterase, whereas non-viable cells showed red fluorescence due to the diffusion of ethidium homodimer across damaged cell membranes and binding with nucleic acids.

\subsection{Statistical analysis}

The average values and standard deviation were calculated from the numerical data and plotted. Statistical analysis was conducted using the standard analysis of variance method and post-hoc analysis with the Bonferroni correction. Statistical significance was considered at $\mathrm{p}<0.05$. 


\section{Results}

\subsection{Microstructure and phase composition}

$\mathrm{X}$-ray diffraction patterns of the alloys were shown in Figure 1. It indicates that the investigated alloys possess different phase compositions. In the ternary alloy, only $\mathrm{Mg}_{2} \mathrm{Ca}$ secondary phase is detected. With the addition of different amounts of $\mathrm{Zn}$, other secondary phases, including $\mathrm{CaZn}_{3}, \mathrm{Ca}_{2} \mathrm{Mg}_{5} \mathrm{Zn}_{13}$ and $\mathrm{Ca}_{2} \mathrm{Mg}_{6} \mathrm{Zn}_{3}$, are formed. The diffraction peaks of $\mathrm{Ca}_{2} \mathrm{Mg}_{6} \mathrm{Zn}_{3}$ phase are increasing with the further addition of $\mathrm{Zn}$ in the alloys.

The microstructures of the alloys observed by SEM were illustrated in Figure 2. The SEM images exhibit a typical metallographic microstructural feature. As we can see from Figure 2, the $\mathrm{Mg}-1 \mathrm{Ca}-0.5 \mathrm{Sr}$ ternary alloys exhibit larger grain size when compared with $\mathrm{Zn}$ containing alloys. The secondary phases in the alloys were mainly distributed along the grain boundaries. The $\mathrm{Mg}-1 \mathrm{Ca}-0.5 \mathrm{Sr}$ alloy exhibited coarser grain boundaries. In the $\mathrm{Zn}$ containing quaternary alloys, some round particles (indicated by the black arrows) were present in the grains. With more $\mathrm{Zn}$ contents in the alloys, more deposited secondary phases could be found. Figure 3 shows the chemical compositions of the secondary phases indicated by the black arrows in Figure 1 and detected by EDS analysis. Oxygen derived from the oxidation reaction during polishing and etching process was detected in all the alloys samples. The atomic percentage of the alloying elements such as $\mathrm{Ca}, \mathrm{Sr}$ and $\mathrm{Zn}$ was increased with the increment of $\mathrm{Zn}$ contents.

\subsection{Corrosion behavior of the alloys}

The morphology of alloys after immersed in Hank's solution for 10 days is exhibited in Figure 4. All the samples are covered with a layer of corrosion products and corrosion cracks can be seen on the surface due to the dehydration procedure. The congregation of local corrosion products can be seen in the inset image of $\mathrm{Zn}$ containing alloys (Figure $4 \mathrm{~b}, \mathrm{c}, \mathrm{d}$ ). Local corrosion pit can be seen in the inset image of $\mathrm{Mg}-1 \mathrm{Ca}-0.5 \mathrm{Sr}$ alloys (Figure 4a). The EDS spectra were taken from the corrosion products indicated by the black arrows in Figure 4 after the materials were immersed in Hank's solution for 10 days. The results were depicted in Figure 5. Figure 5 shows that the majority of the corrosion products were composed of $\mathrm{O}$ and $\mathrm{Ca}$ elements. The alloying elements $\mathrm{Sr}$ and $\mathrm{Zn}$, along with $\mathrm{O}, \mathrm{C}, \mathrm{P}$ elements were also detected. $\mathrm{Zn}$ and $\mathrm{Sr}$ in the corrosion products had significantly lower contents than $\mathrm{Ca}$, indicating that only small amounts of $\mathrm{Zn}$ and $\mathrm{Sr}$ compounds were deposited on the sample surfaces. The EDS results suggested that the corrosion products were mainly carbonates, phosphates or oxides.

\subsection{Hydrogen evolution rate and $\mathrm{pH}$ value of the immersion solution}

The hydrogen evolution rate curves are depicted in Figure 6a. The Mg-1Ca-0.5Sr alloy exhibited a higher hydrogen release rate in the first $100 \mathrm{~h}$. While for the $\mathrm{Zn}$ containing alloys, the hydrogen evolution rate was increased with the increasing immersion periods. However, the hydrogen evolution rate of $\mathrm{Mg}-1 \mathrm{Ca}-0.5 \mathrm{Sr}-4 \mathrm{Zn}$ alloy was lower than that of $\mathrm{Mg}-1 \mathrm{Ca}-0.5 \mathrm{Sr}$ alloy during the whole immersion periods. Moreover, for the quaternary alloys, the hydrogen evolution rate was increased during the immersion periods. $\mathrm{Mg}-1 \mathrm{C}-0.5 \mathrm{Sr}$ alloys suffered a faster degradation rate in the initial immersion periods. All 
the $\mathrm{pH}$ values of the samples solution increased with the increasing immersion time (Figure $6 \mathrm{~b})$. After 5 days' immersion, the $\mathrm{pH}$ value of the samples with $\mathrm{Zn}$ addition became steady, while the $\mathrm{pH}$ value of $\mathrm{Mg}-1 \mathrm{Ca}-0.5 \mathrm{Sr}$ alloy solution kept increasing during the whole immersion periods. With the addition of $\mathrm{Zn}$ in the alloy, the $\mathrm{pH}$ value was a little higher than the $\mathrm{Mg}-1 \mathrm{Ca}-0.5 \mathrm{Sr}$ alloy.

\subsection{The osmolality, $\mathrm{pH}$ value and ion concentration of the extracts}

Figure 7 shows the osmolality and $\mathrm{pH}$ value detect from the extracts media. The $\mathrm{pH}$ value of all the extracts exhibited only a little fluctuation within $7.0 \pm 1.0$ and there was no significant differences between the Ti-6Al-4V group and the Zn-containing group. Nevertheless, significant difference between $\mathrm{Mg}-1 \mathrm{Ca}-0.5 \mathrm{Sr}$ group and the Ti-6Al-4V control group was observed (Figure 7). The osmolality value of all the Mg alloy extracts did not show any significant difference in comparison to the Ti-6Al-4V control group.

The change in the ion concentration of the PBS extracts is illustrated in Figure 8. It shows higher $\mathrm{Mg}$ ion concentration in $\mathrm{Zn}$ containing alloys than in $\mathrm{Mg}-1 \mathrm{Ca}-0.5 \mathrm{Sr}$ group. The $\mathrm{Zn}$ ion concentration was different for different alloy groups with about $0.05 \pm 0.01 \mu \mathrm{g} / \mathrm{ml}$ for $\mathrm{Mg}-1 \mathrm{Ca}-0.5 \mathrm{Sr}-2 \mathrm{Zn}, 0.48 \pm 0.15 \mu \mathrm{g} / \mathrm{ml}$ for $\mathrm{Mg}-1 \mathrm{Ca}-0.5 \mathrm{Sr}-4 \mathrm{Zn}$ and $0.89 \pm 0.08 \mu \mathrm{g} / \mathrm{ml}$ for $\mathrm{Mg}-1 \mathrm{Ca}-0.5 \mathrm{Sr}-6 \mathrm{Zn}$. The concentration of the $\mathrm{Ca}$ ion in the extracts were quite similar among all the groups. While for the $\mathrm{Sr}$ ions, the $\mathrm{Mg}-1 \mathrm{Ca}-0.5 \mathrm{Sr}-4 \mathrm{Zn}$ alloys exhibited a much higher $\mathrm{Sr}$ ion concentration than other groups.

\subsection{Indirect bactericidal assays}

In order to figure out whether the Mg alloys extracts possessed antibacterial effect or not, bacteria were incubated for $24 \mathrm{~h}$ in PBS extracts of experimental alloy samples. After incubation, the number of viable bacteria for all extracts from the $\mathrm{Mg}$ alloys samples decreased compared with that of the Ti-6Al-4V control group (Figure 9). The Zn containing alloys could achieve a killing rate of approximately $90 \%$. However, in contrast, the number of CFUs for $\mathrm{Mg}-1 \mathrm{Ca}-0.5 \mathrm{Sr}$ alloy exhibited a reduction only about $28 \%$ when compared with Ti-6Al-4V control group. The inhibitory effects of all the materials on the bacterial were in such an order as $\mathrm{Mg}-1 \mathrm{Ca}-0.5 \mathrm{Sr}-6 \mathrm{Zn}<\mathrm{Mg}-1 \mathrm{Ca}-0.5 \mathrm{Sr}-4 \mathrm{Zn}<\mathrm{Mg}-1 \mathrm{Ca}-0.5 \mathrm{Sr}-2 \mathrm{Zn} \ll \mathrm{Mg}-1 \mathrm{Ca}-0.5 \mathrm{Sr}<\mathrm{Ti}-6 \mathrm{Al}-4 \mathrm{~V}$ control group. The tendency of the increased antibacterial activity with increasing $\mathrm{Zn}$ contents in alloys was observed and $\mathrm{Mg}-1 \mathrm{Ca}-0.5 \mathrm{Sr}-6 \mathrm{Zn}$ was identified as most potent antibacterial material.

\subsection{Antibacterial curves}

Indirect antibacterial assay suggested that all the $\mathrm{Mg}$ alloys extracts extracted for $72 \mathrm{~h}$ had antibacterial or even bactericidal activity. Then we conducted another test to evaluate the antibacterial property of the extracts derived from the alloys under different extraction time. Antibacterial curves for the S. aureus inoculated in Ti-6Al-4V control group or in Mg alloys groups are depicted in Figure 10. Compared to the Ti-6Al-4V control group, all the Mg alloy exhibited a slight inhibition effect on the bacterial growth after $6 \mathrm{~h}$ extract. But there is no significant differences among the $\mathrm{Mg}$ alloys groups before $48 \mathrm{~h}$ extraction was observed. With further increasing the extraction time to $72 \mathrm{~h}$ and $96 \mathrm{~h}$, the viable bacteria for the $\mathrm{Zn}$ - 
containing alloys exhibited a sharp drop to the level where no viable bacteria could be seen on the plates. However, the viable bacteria of $\mathrm{Mg}-1 \mathrm{Ca}-0.5 \mathrm{Sr}$ group remained constant during the whole incubation periods. For the $\mathrm{Zn}$ containing quaternary alloys, the number of viable bacteria on the plates decreased with the increment of the $\mathrm{Zn}$ content in the alloys.

\subsection{Direct bactericidal assay}

In order to analyze the direct antibacterial effect of $\mathrm{Mg}$ alloys with different $\mathrm{Zn}$ content, the number of bacteria on the alloys was evaluated. The amount of adhered bacteria on all the alloy samples are illustrated in Figure 11. It can be seen that the average values for viable bacteria adhered on $\mathrm{Mg}$ alloys were all obviously lower than the control groups (Ti-6Al-4V). The killing rate of the Mg-1Ca-0.5Sr-4Zn and Mg-1Ca-0.5Sr-6Zn was higher than $96.6 \%$. It was interesting to note that $\mathrm{Mg}-1 \mathrm{Ca}-0.5 \mathrm{Sr}-2 \mathrm{Zn}$ exhibited a relative lower killing rate of $76.9 \%$, and meanwhile, $\mathrm{Mg}-1 \mathrm{Ca}-0.5 \mathrm{Sr}$ also exhibited a strong antibacterial effect with a killing rate higher than $90 \%$, which was much higher than $\mathrm{Mg}-1 \mathrm{Ca}-0.5 \mathrm{Sr}-2 \mathrm{Zn}$ alloy (Figure 11f).

\subsection{Bacterial Adhesion assay}

The vitality of bacteria adhered on the alloy samples surfaces observed by fluorescent microscopy is displayed in Figure 12. Live bacteria were stained in green, whereas dead bacteria manifested in red. The Ti-6Al-4V alloy surface is covered with a layer of live bacteria. The results suggest that the number of live bacteria on $\mathrm{Mg}$ alloy samples is remarkably lower than that on Ti-6Al-4V control group. In addition, large number of dead bacteria can be seen on Mg alloy samples.

The fluorescent images of the bacterial cells stained with DAPI are shown in Figure 13 and the adhered bacteria number counted in five random fields is illustrated in Figure 14. From the Figure 13, we can find that all the alloy samples showed similar bacteria adhesion on the surfaces after $30 \mathrm{~min}$ of culture. When the incubation time increased to $60 \mathrm{~min}$, the bacteria adhered on the alloys surfaces exhibited a decline tendency in comparison to that at $30 \mathrm{~min}$ (Figure 14). However, the number of bacteria attached on the Ti-6Al-4V control group was increased (Figure 14). After $90 \mathrm{~min}$, the adhered bacteria on all the Mg alloy surfaces dramatically decreased, while the Ti-6Al-4V control group still showed an increase in the number of adherent bacteria (Figure 14).

SEM observation was performed to examine the morphology and number of the adhered bacteria and the results are depicted in Figure 15. It was found that the bacteria maintained their normal shape after incubation for $4 \mathrm{~h}$. However, the number of bacteria on the $\mathrm{Mg}$ alloys surface exhibited significant decrease when compared with that of Ti-6Al-4V control group. We can conclude that Mg alloy can significantly inhibit the growth of bacteria and the adherence of the bacteria on the alloys surfaces.

\subsection{Cytotoxicity}

MTT assay was used to assess the cell proliferation of MC3T3-E1 cells cultured in different $\mathrm{Mg}$ alloys extracts for 2, 4, and 6 days. The cell viability is shown in Figure 16. It can be seen that the morphology of MC3T3 cells in different extracts was in spindle-like shape, 
which was similar to that of the control group (Figure 16). As is shown in Figure 16(f), cells cultured in the $\mathrm{Mg}$ alloys extracts showed relatively similar absorbance in comparison to the control group on the first 2 days ( $>0.05$ ). Afterwards, the absorbance of all the groups was increased drastically, indicating the increase in the number of living cells. On day 4, the number of cells on the Mg-1Ca-0.5Sr group was slightly higher than that on the Ti-6Al-4V control group $(\mathrm{p}<0.05)$. Meanwhile, the number of the cells on the other three alloy groups had no statistically significant differences compared with the Ti-6Al-4V control group (p>0.05). After 6 days, although all the $\mathrm{Mg}$ alloys still exhibit a high absorbance, we can see that the cell growth rate showed a mild drop with the increase of $\mathrm{Zn}$ content, and the $\mathrm{Mg}-1 \mathrm{Ca}-0.5 \mathrm{Sr}$ group showed a statistical differences compared to the control group with an inhibition rate of about $20 \%$.

The images of Live/Dead assay are exhibited in Figure 17. The results showed that there were a slight increase in the number of dead cells with the increase in the $\mathrm{Zn}$ content. The number of the dead cells on the $\mathrm{Mg}-1 \mathrm{Ca}-0.5 \mathrm{Sr}$ alloys were lower than the $\mathrm{Mg}-1 \mathrm{Ca}-0.5 \mathrm{Sr}-6 \mathrm{Zn}$ alloys after 6 days of incubation. Although a few numbers of dead cells can be seen in all the alloys extracts, the viability of the cells in Mg-Ca-Sr-Zn quaternary alloys are still higher than $80 \%$ after 6 days incubation.

\section{Discussion}

Bacterial infection frequently threatens the health of patients and has become the predominant causes of biomaterial implant failures. ${ }^{1} \mathrm{Mg}-\mathrm{Ca}, \mathrm{Mg}-\mathrm{Sr}, \mathrm{Mg}-\mathrm{Zn}$ binary alloys have been proved to be promising orthopedic biomaterials with excellent biocompatibility and good in vivo behavior. ${ }^{16,17,19}$ As anti-bacterial elements, both $\mathrm{Zn}$ and Sr were widely used in bioactive glasses for bone repairing applications. The results of this study found that our prepared $\mathrm{Mg}$-Ca-Sr-Zn alloys exhibited both good anti-bacterial property and good biocompatibility.

\subsection{Microstructure and in vitro corrosion behavior}

$\mathrm{Zn}$ has been reported to be an efficient grain refiner for $\mathrm{Mg}$ alloys. In our present work, the SEM images confirmed that the addition of $\mathrm{Zn}$ in the $\mathrm{Mg}-1 \mathrm{Ca}-0.5 \mathrm{Sr}$ alloy led to the refinement of the grain size (Figure 2). The maximum solubility of the $\mathrm{Zn}$ in $\mathrm{Mg}$ is $6.2 \mathrm{wt} . \%$ at $325^{\circ} \mathrm{C}$, however, $\mathrm{Zn}$ containing phases including $\mathrm{CaZn}_{3}, \mathrm{Ca}_{2} \mathrm{Mg}_{5} \mathrm{Zn}_{13}$ and $\mathrm{Ca}_{2} \mathrm{Mg}_{6} \mathrm{Zn}_{3}$ were also detected according to XRD analysis (Figure 1). It suggested that the solubility of $\mathrm{Zn}$ in $\mathrm{a}-\mathrm{Mg}$ was decreased and the compounds were formed when other alloying elements were added. Furthermore, with higher $\mathrm{Zn}$ contents in the alloys, more $\mathrm{Zn}$ containing secondary phases were deposited in the grains or along the grain boundaries (Figure 2, 3).

Immersion test and hydrogen evolution test are two common and efficient approaches for evaluating the in vitro degradation behavior of the alloys for biomedical applications. After 10 days of immersion in Hank's solution, the sample surface was mainly covered with a layer of carbonates and phosphates. ${ }^{17} \mathrm{Sr}$ and $\mathrm{Zn}$ were also detected in the corrosion products (Figure 5b), indicating that the degradation of the alloys may also form $\mathrm{Sr}$ and $\mathrm{Zn}$ containing salts or oxides. $\mathrm{Mg}-1 \mathrm{Ca}-0.5 \mathrm{Sr}$ alloy exhibited a local corrosion mode with corrosion pits on 
the surface. With the addition of $\mathrm{Zn}$ to the ternary alloy, no corrosion pit can be seen. The alloying element of $\mathrm{Zn}$ resulted in more homogenous corrosion of the alloys.

During the initial period, the hydrogen evolution rate of the $\mathrm{Mg}-1 \mathrm{Ca}-0.5 \mathrm{Sr}$ was higher than that of $\mathrm{Zn}$-containing alloys. The fast degradation rate resulted in the higher $\mathrm{pH}$ value of the immersion medium (Figure $6 \mathrm{~b}$ ). With the increasing immersion time, the corrosion products deposited on the alloy acted as a protective layer and inhibited the permeation of the corrosive medium (Figure 4a). Thus, the hydrogen evolution rate decreased (Figure 6a). The released cations from the degradation process consumed the $\mathrm{OH}^{-}$to form the deposits and $\mathrm{pH}$ value of the medium in $\mathrm{Mg}-1 \mathrm{Ca}-0.5 \mathrm{Sr}$ alloy group increased more slowly than other alloy groups (Figure $6 \mathrm{~b}$ ). With further increase in the immersion time, the corrosion product layer was broken down by the medium, and fresh alloy matrix was exposed to the medium and the hydrogen evolution rate and volume were then increased. The $\mathrm{Zn}$ containing alloys exhibited a slower degradation rate at the first 100 hours and Mg-1Ca- $0.5 \mathrm{Sr}-4 \mathrm{Zn}$ alloy showed a better corrosion resistance during the whole immersion period. Moreover, $\mathrm{Mg}-1 \mathrm{Ca}-0.5 \mathrm{Sr}-6 \mathrm{Zn}$ alloy exhibited higher hydrogen evolution rate.

\subsection{Indirect antibacterial assays}

As was described in the previous sections, the bacterial colony formation numbers according to the indirect assay were decreased with the increasing $\mathrm{Zn}$ contents. It was widely regarded that osmolality and $\mathrm{pH}$ value of the culture medium were two common factors that important for the growth of cells and bacteria. Due to the buffering capacity of the PBS solution, we found that both the osmolality and $\mathrm{pH}$ of the PBS extracts exhibited little fluctuation between the alloys with different $\mathrm{Zn}$ contents, while the $\mathrm{pH}$ value of $\mathrm{Mg}-1 \mathrm{Ca}-0.5 \mathrm{Sr}$ alloy showed a statistically significant difference compared with the Ti-6Al-4V control group (Figure 7). All the osmolality and $\mathrm{pH}$ values of the PBS extracts were in the suitable ranges for the growth of bacteria. However, the ions concentration of the PBS extracts was different from each alloy (Figure 8). Robinson et al ${ }^{6}$ evaluated the antibacterial properties of $\mathrm{Mg}$ metal in vitro. They found that the increment of $\mathrm{Mg}^{2+}$ ions released from the corrosion process alone had no anti-bacterial effect, but the increment in the $\mathrm{pH}$ value of the extracts inhibited the growth of bacteria. In our study, there was only little difference of the $\mathrm{Ca}^{2+}$ ions concentration among the four alloys, and thus we concluded that the anti-bacterial property of the $\mathrm{Mg}-\mathrm{Ca}-\mathrm{Sr}-\mathrm{Zn}$ alloys had little correlation with the $\mathrm{Ca}^{2+}$ and $\mathrm{Mg}^{2+}$ ions. Taking this finding into consideration, the $\mathrm{Sr}^{2+}$ and $\mathrm{Zn}^{2+}$ in the PBS extractions may contribute to the anti-bacterial effect of the $\mathrm{Mg}-\mathrm{Ca}-\mathrm{Sr}-\mathrm{Zn}$ alloys. ${ }^{37}$ Furthermore, the number of CFUs of the $\mathrm{Mg}-\mathrm{Ca}-\mathrm{Sr}-\mathrm{Zn}$ alloys was decreased with the increment of $\mathrm{Zn}^{2+}$ ion concentration (Figure 8, Figure 9), indicating that $\mathrm{Zn}^{2+}$ ion improved the anti-bacterial property. It was reported that the addition of $\mathrm{Sr}$ resulted in a dose dependent bactericidal effect in the bioactive cements. ${ }^{38}$ An in vivo result also showed that the Sr-doped 45S5 bioglass didn't cause any inflammation. ${ }^{39}$ After half or totally substituted the $\mathrm{Ca}$ in the hydroxyapatite (HA) with $\mathrm{Sr}$, the anti-bacterial effects of HA were improved. ${ }^{40}$ Many studies ${ }^{33,41}$ had demonstrated that $\mathrm{Zn}$ possessed excellent antibacterial ability and exhibited antibacterial effect, especially on gram-positive bacteria. Södeberg et al ${ }^{42}$ found that gram-positive bacteria were the most susceptible bacterial group to $\mathrm{Zn}$ ions and much more susceptible than gram-negative aerobic bacteria. It was reported that a relatively higher 
$\mathrm{Zn}$ ion concentration of about $1024 \mu \mathrm{g} / \mathrm{ml}$ showed no inhibition effect on the gram-negative aerobic bacteria, while for the gram-positive bacteria, a concentration of about 100-110 $\mu \mathrm{l} / \mathrm{ml}$ exhibited inhibition effects. Selahattin et al ${ }^{43}$ also found that it had an inhibition effect on S. aureus with a $\mathrm{Zn}$ concentration of about $36.4 \mu \mathrm{l} / \mathrm{ml}$. Furthermore, Jin et $\mathrm{al}^{29}$ reported that the minimum inhibition concentration of $\mathrm{Zn}$ ions for $S$. aureus was lower than $9 \mu \mathrm{g} / \mathrm{ml}$. On the other hand, Franklin et al ${ }^{44}$ concluded that $\mathrm{Zn}$ ions released from $\mathrm{ZnO}$ was the main reason for the antibacterial property. They found that it showed a strong inhibition effect on S. aureus when the concentration of $\mathrm{Zn}$ ion was around $10 \mu \mathrm{g} / \mathrm{ml}$, which was in accordance with Jin's work ${ }^{29}$. In this study, the effective concentration of $\mathrm{Zn}$ ions from the $\mathrm{Zn}$ containing Mg alloys was very low, which was about $0.05 \mu \mathrm{g} / \mathrm{mL}$ for $\mathrm{Mg}-1 \mathrm{Ca}-0.5 \mathrm{Sr}-2 \mathrm{Zn}$, $0.48 \mu \mathrm{g} / \mathrm{mL}$ for $\mathrm{Mg}-1 \mathrm{Ca}-0.5 \mathrm{Sr}-4 \mathrm{Zn}$ and $0.89 \mu \mathrm{g} / \mathrm{mL}$ for $\mathrm{Mg}-1 \mathrm{Ca}-0.5 \mathrm{Sr}-6 \mathrm{Zn}$. While the low $\mathrm{Zn}$ ion concentration in this work revealed the same inhibition effects as in the previous studies, our findings suggested that the combination of $\mathrm{Zn}$ ion and $\mathrm{Sr}$ ions exhibited better antibacterial property compared to zinc ions alone.

The results of Mg-Ca-Sr-Zn alloys extracts at different time points on bacterial growth revealed that the $\mathrm{Zn}$ containing alloys continuously provide anti-bacterial effects when compared with the $\mathrm{Mg}-1 \mathrm{Ca}-0.5 \mathrm{Sr}$ and $\mathrm{Ti}-6 \mathrm{Al}-4 \mathrm{~V}$ control group. Moreover, the killing rate of the extracts with an extraction time of $72 \mathrm{~h}$ was dramatically increased (Figure 10). In order to minimize the side effects of the antibiotics and achieve the best antibacterial effect, we concluded that when these alloys were used in clinical practice, the use of topical antimicrobial agents should be gradually reduced in 72 hours after surgery.

\subsection{Direct antibacterial assays}

The results of direct antibacterial assays exhibited that the alloys not only inhibited the bacteria's growth but also decreased the number of the adhered bacteria on the alloys surfaces. $\mathrm{Mg}-1 \mathrm{Ca}-0.5 \mathrm{Sr}$ alloy exhibited a comparable antibacterial property with $\mathrm{Mg}-1 \mathrm{Ca}-0.5 \mathrm{Sr}-4 \mathrm{Zn}$ and $\mathrm{Mg}-1 \mathrm{Ca}-0.5 \mathrm{Sr}-6 \mathrm{Zn}$ alloys. The antibacterial efficiency of $\mathrm{Mg}-1 \mathrm{Ca}-0.5 \mathrm{Sr}-2 \mathrm{Zn}$ alloy was significantly lower than that of the other three $\mathrm{Mg}$ alloys. As was shown in Figure 15, after incubation with the bacteria for $6 \mathrm{~h}$, the alloys surface were covered with a layer of corrosion products and corrosion cracks could also be seen. The bacteria with normal shape was adhered on the corrosion products, and the number of bacteria varies with the $\mathrm{Zn}$ content in the alloys. During the whole incubation periods, gas evolution immediately took place on the surface of the alloys. The resultant gas bubbles would hinder the bacterial adherence on the alloy surface. The released $\mathrm{OH}^{-}$derived from the alloys degradation increased the local $\mathrm{pH}$ value, which may further have an impact on the adherence and growth of bacteria. Furthermore, the corrosion products on the sample surfaces may also play an important role on bacterial adherence. It has been reported that the corrosion products formed during the alloy degradation process contributed to bacterial death. Both Dong et al ${ }^{45}$ and Jin et $\mathrm{al}^{46}$ reported the antibacterial effects of $\mathrm{Mg}(\mathrm{OH})_{2}$ and $\mathrm{MgO}$. Other scholar ${ }^{44}$ also reported that $\mathrm{ZnO}$ exhibited good antimicrobial efficacy. Kishen et al ${ }^{47}$ found that the $\mathrm{ZnO}$ nanoparticles produced a significant reduction in the number of E. faecalis cells adhered to dentin. The increment of $\mathrm{Zn}^{2+}$ ions would also be an important factor that helped the anti-adherence of bacteria. We can speculate that the formation of the oxides on the surface of the samples and the rapid release of hydrogen gas and $\mathrm{OH}^{-}$may 
contribute to the anti-adherence of the bacteria on the Mg alloys (Figure 5-6). Additionally, the increase in ion concentrations (especially $\mathrm{Zn}$ ion) and $\mathrm{pH}$ values may also have an influence on the growth of bacteria. The immersion medium of $\mathrm{Mg}-1 \mathrm{Ca}-0.5 \mathrm{Sr}-2 \mathrm{Zn}$ alloy group exhibited a lower $\mathrm{pH}$ value than other three $\mathrm{Mg}$ alloys. While the hydrogen evolution rate of the $\mathrm{Mg}-1 \mathrm{Ca}-0.5 \mathrm{Sr}-2 \mathrm{Zn}$ alloy was also slower than that of the $\mathrm{Mg}-1 \mathrm{Ca}-0.5 \mathrm{Sr}-6 \mathrm{Zn}$ alloy. Thus the number of adhered bacteria was higher than other Mg alloys, which may be the reason for its lower direct antibacterial and anti-adherence efficiency.

The result of Live/Dead staining assay and SEM observation give us an overview of the number of the bacteria on the samples. These findings were in agreement with that of the direct antibacterial test (Figure 11f), further confirming the antibacterial effect of the $\mathrm{Mg}$ alloys. The DAPI staining assay used to evaluate the early anti-adhesion property of the alloys. The results indicated that all the $\mathrm{Mg}$ alloys could inhibit the adhesion of bacteria when compared with the Ti-6Al-4V control group (Figure 13, 14). Furthermore, the continuous corrosion process would result in the continuous release of hydrogen bubbles and $\mathrm{OH}^{-}$near the sample surface, thus the $\mathrm{Mg}$ alloys can continuous inhibit the bacterial adherence while the adhered bacteria on the Ti-6Al-4V surface was increased with the increasing incubation time.

\subsection{Cytotoxicity}

$\mathrm{Ca}, \mathrm{Sr}$ and $\mathrm{Zn}$ are all essential metal element for human daily metabolism. Previous studies had already shown that these alloying elements possess good biocompatibility and osteogenic activity. In our MTT assay, the Mg-Ca-Sr-Zn alloys exhibited no obvious toxicity to MC3T3 -E1 cells and the cytotoxicity of all the alloys extracts was found to be Grade 0-1 (Figure 16). We can see that the Zn-containing alloys exhibited a higher biocompatibility than $\mathrm{Mg}-1 \mathrm{Ca}-0.5 \mathrm{Sr}$. The optical images showed that the cells were spread to have a spindle-like shape. Fluorescence images also depicted that the culture disk was covered with a layer of MC3T3-E1 cells, and only a small amount of dead cells were found (Figure 17). Our results indicated that these alloys are safe enough to be used as a potential biomaterial for orthopedic applications.

\section{Conclusions}

Our results clearly showed that zinc addition into $\mathrm{Mg}-1 \mathrm{Ca}-0.5 \mathrm{Sr}$ to form $\mathrm{Mg}-1 \mathrm{Ca}-0.5 \mathrm{Sr}-4 \mathrm{Zn}$ decreased the hydrogen evolution volume and evolution rate, while bringing no additional toxicity compared to the $\mathrm{Mg}-1 \mathrm{Ca}-0.5 \mathrm{Sr}$ alloy. Moreover, $\mathrm{Mg}-1 \mathrm{Ca}-0.5 \mathrm{Sr}-6 \mathrm{Zn}$ exhibited a stronger antibacterial effect against $S$. aureus than $\mathrm{Mg}-1 \mathrm{Ca}-0.5 \mathrm{Sr}$. We can conclude that $\mathrm{Mg}-1 \mathrm{Ca}-0.5 \mathrm{Sr}-6 \mathrm{Zn}$ was the best choice as an ideal antibacterial biodegradable orthopedic implant material since it not only has better antibacterial effect as $\mathrm{Mg}-1 \mathrm{Ca}-0.5 \mathrm{Sr}-2 \mathrm{Zn}$ and $\mathrm{Mg}-1 \mathrm{Ca}-0.5 \mathrm{Sr}-4 \mathrm{Zn}$ but also shows a comparable efficiency on promoting the growth of osteoblasts. This study shows that $\mathrm{Mg}-1 \mathrm{Ca}-0.5 \mathrm{Sr}-6 \mathrm{Zn}$ is a multifunctional antibacterial biodegradable implant that can be used in bone surgery to prevent bacterial infections. 


\section{Acknowledgments}

This work was financed by National Natural Science Foundation of China (Grant No.81271957), National Basic Research Program of China (Grant No.2012CB619106) and Guangdong Key Lab of Orthopedic Technology and Implant Materials Construction Grant (No. 2011233-32).

Yufeng Zheng would like to thank the financial support by the National Basic Research Program of China (973 Program) (Grant No. 2012CB619102 and 2012CB619100), National Science Fund for Distinguished Young Scholars (Grant No. 51225101), National Natural Science Foundation of China (Grant No. 51431002).

Y.Zhu. and C.B.M. would also like to thank the financial support from National Science Foundation (DMR-0847758, CMMI-1234957, CBET-0854414), National Institutes of Health (1R21EB015190), Department of Defense Peer Reviewed Medical Research Program (W81XWH-12-1-0384), Oklahoma Center for the Advancement of Science and Technology (HR14-160) and Oklahoma Center for Adult Stem Cell Research (434003).

\section{References}

1. Wang JC, Wang ZP, Guo S, Zhang JY, Song Y, Dong XM, Wang XN, Yu JH. Micropor Mesopor Mat. 2011; 146:216-222.

2. Miola M, Bruno M, Maina G, Fucale G, Lucchetta G, Verne E. Mat Sci Eng C-Mater. 2014; 43:6575.

3. Nablo BJ, Rothrock AR, Schoenfisch MH. Biomaterials. 2005; 26:917-924. [PubMed: 15353203]

4. Mei SL, Wang HY, Wang W, Tong LP, Pan HB, Ruan CS, Ma QL, Liu MY, Yang HL, Zhang L, Cheng YC, Zhang YM, Zhao LZ, Chu PK. Biomaterials. 2014; 35:4255-4265. [PubMed: 24565524]

5. Zhou PY, Xia Y, Cheng XS, Wang PF, Xie Y, Xu SG. Biomaterials. 2014; 35:10033-10045. [PubMed: 25260421]

6. Robinson DA, Griffith RW, Shechtman D, Evans RB, Conzemius MG. Acta biomaterialia. 2010; 6:1869-1877. [PubMed: 19818422]

7. Massa MA, Covarrubias C, Bittner M, Fuentevilla IA, Capetillo P, Von Marttens A, Carvajal JC. Materials Science and Engineering: C. 2014; 45:146-153. [PubMed: 25491813]

8. Liu J, Li FB, Liu C, Wang HY, Ren BR, Yang K, Zhang EL. Mat Sci Eng C-Mater. 2014; 35:392400.

9. Arciola CR, Alvi FI, An YH, Campoccia D, Montanaro L. Int J Artif Organs. 2005; 28:1119-1125. [PubMed: 16353118]

10. Fielding GA, Roy M, Bandyopadhyay A, Bose S. Acta biomaterialia. 2012; 8:3144-3152. [PubMed: 22487928]

11. Song G, Atrens A, St John D, Wu X, Nairn J. Corros Sci. 1997; 39:1981-2004.

12. Staiger MP, Pietak AM, Huadmai J, Dias G. Biomaterials. 2006; 27:1728-1734. [PubMed: 16246414]

13. Witte F, Kaese V, Haferkamp H, Switzer E, Meyer-Lindenberg A, Wirth CJ, Windhagen H. Biomaterials. 2005; 26:3557-3563. [PubMed: 15621246]

14. Brar HS, Platt MO, Sarntinoranont M, Martin PI, Manuel MV. Jom. 2009; 61:31-34.

15. Peeters P, Bosiers M, Verbist J, Deloose K, Heublein B. J Endovasc Ther. 2005; 12:1-5. [PubMed: 15683259]

16. Gu XN, Xie XH, Li N, Zheng YF, Qin L. Acta biomaterialia. 2012; 8:2360-2374. [PubMed: 22387336]

17. Li ZJ, Gu XN, Lou SQ, Zheng YF. Biomaterials. 2008; 29:1329-1344. [PubMed: 18191191]

18. Krause A, von der Hoh N, Bormann D, Krause C, Bach FW, Windhagen H, Meyer-Lindenberg A. J Mater Sci. 2010; 45:624-632.

19. Zhang SX, Zhang XN, Zhao CL, Li JA, Song Y, Xie CY, Tao HR, Zhang Y, He YH, Jiang Y, Bian YJ. Acta biomaterialia. 2010; 6:626-640. [PubMed: 19545650]

20. Yin P, Li NF, Lei T, Liu L, Ouyang C. J Mater Sci-Mater M. 2013; 24:1365-1373. [PubMed: 23608999] 
21. Marie PJ, Garba MT, Hott M, Miravet L. Miner Electrol Metab. 1985; 11:5-13.

22. Marie PJ. Osteoporosis Int. 2005; 16:S7-S10.

23. Dahl SG, Allain P, Marie PJ, Mauras Y, Boivin G, Ammann P, Tsouderos Y, Delmas PD, Christiansen C. Bone. 2001; 28:446-453. [PubMed: 11336927]

24. Tournis S. J Musculoskelet Neuronal Interact. 2007; 7:266-267. [PubMed: 17947810]

25. Brar HS, Wong J, Manuel MV. Journal of the mechanical behavior of biomedical materials. 2012; 7:87-95. [PubMed: 22340688]

26. Lee YC, Dahle AK, StJohn DH. Metall Mater Trans A. 2000; 31:2895-2906.

27. Berglund IS, Brar HS, Dolgova N, Acharya AP, Keselowsky BG, Sarntinoranont M, Manuel MV. J Biomed Mater Res B. 2012; 100B:1524-1534.

28. Brandt EG, Hellgren M, Brinck T, Bergman T, Edholm O. Physical Chemistry Chemical Physics. 2009; 11:975-983. [PubMed: 19177216]

29. Jin GD, Cao HL, Qiao YQ, Meng FH, Zhu HQ, Liu XY. Colloid Surface B. 2014; 117:158-165.

30. Diez-Pascual AM, Xu CP, Luque R. J Mater Chem B. 2014; 2:3065-3078.

31. Wood TJ, Hurst GA, Schofield WCE, Thompson RL, Oswald G, Evans JSO, Sharples GJ, Pearson C, Petty MC, Badyal JPS. J Mater Chem. 2012; 22:3859-3867.

32. Tarushi A, Psomas G, Raptopoulou CP, Kessissoglou DP. Journal of inorganic biochemistry. 2009; 103:898-905. [PubMed: 19395041]

33. Xua JA, Ding G, Li JL, Yang SH, Fang BS, Sun HC, Zhou YM. Appl Surf Sci. 2010; 256:7540_ 7544.

34. Phan TN, Buckner T, Sheng J, Baldeck JD, Marquis RE. Oral Microbiol Immun. 2004; 19:31-38.

35. Applerot G, Lipovsky A, Dror R, Perkas N, Nitzan Y, Lubart R, Gedanken A. Adv Funct Mater. 2009; 19:842-852.

36. Bornapour M, Muja N, Shum-Tim P, Cerruti M, Pekguleryuz M. Acta biomaterialia. 2013; 9:5319-5330. [PubMed: 22871640]

37. Looney M, O'Shea H, Gunn L, Crowley D, Boyd D. Journal of biomaterials applications. 2013; 27:937-947. [PubMed: 22207607]

38. Brauer DS, Karpukhina N, Kedia G, Bhat A, Law RV, Radecka I, Hill RG. J R Soc Interface. 2013; 10:20120647.

39. Gorustovich AA, Steimetz T, Cabrini RL, Lopez JMP. Journal of Biomedical Materials Research Part A. 2010; 92A:232-237. [PubMed: 19172615]

40. Ravi ND, Balu R, Kumar TSS. J Am Ceram Soc. 2012; 95:2700-2708.

41. Hameed ASH, Karthikeyan C, Sasikumar S, Kumar VS, Kumaresan S, Ravi G. J Mater Chem B. 2013; 1:5950-5962.

42. Söderberg TA, Sunzel B, Holm S, Elmros T, Hallmans G, Sjöberg S. Scandinavian Journal of Plastic and Reconstructive Surgery and Hand Surgery. 1990; 24:193-197. [PubMed: 2281305]

43. Atmaca S. Turkish Journal of Medical Sciences. 1998; 28:595-598.

44. Franklin NM, Rogers NJ, Apte SC, Batley GE, Gadd GE, Casey PS. Environmental science \& technology. 2007; 41:8484-8490. [PubMed: 18200883]

45. Dong CX, Cairney J, Sun QH, Maddan OL, He GH, Deng YL. J Nanopart Res. 2010; 12:21012109.

46. Jin T, He YP. J Nanopart Res. 2011; 13:6877-6885.

47. Kishen A, Shi ZL, Shrestha A, Neoh KG. J Endodont. 2008; 34:1515-1520. 


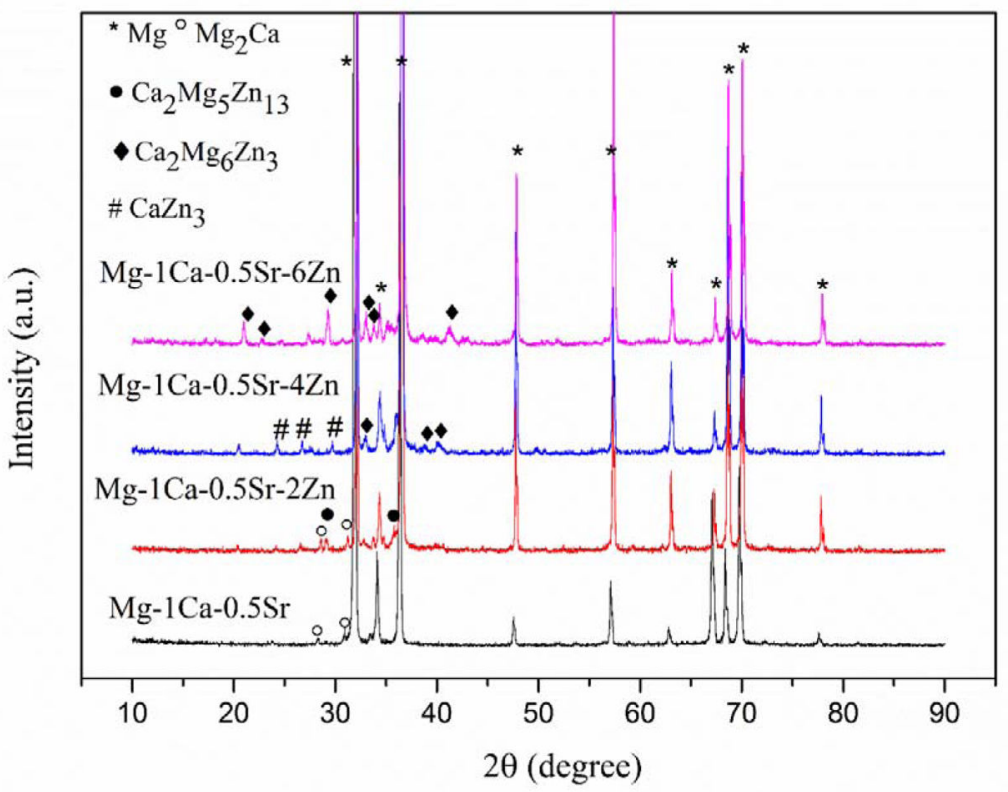

Figure 1.

X-ray diffraction patterns of the experimental alloys 


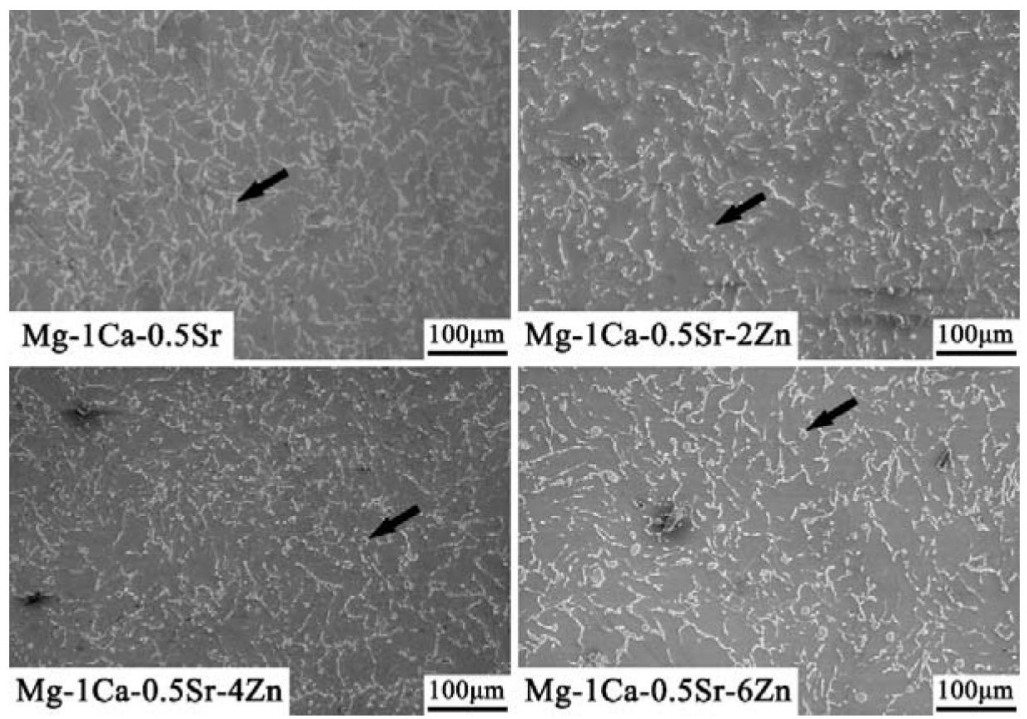

Figure 2.

The SEM images of microstructure of the Mg alloys. The secondary phases in the alloys were indicated by the black arrow. 

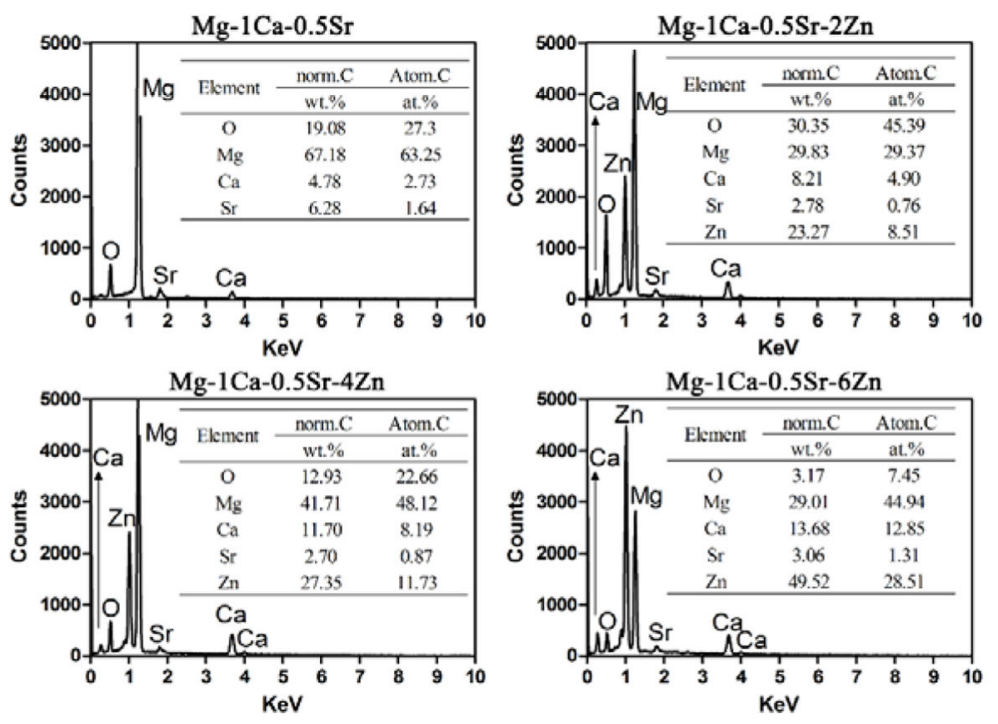

Figure 3.

EDS results of the secondary phases indicated by the arrows in Figure 2 


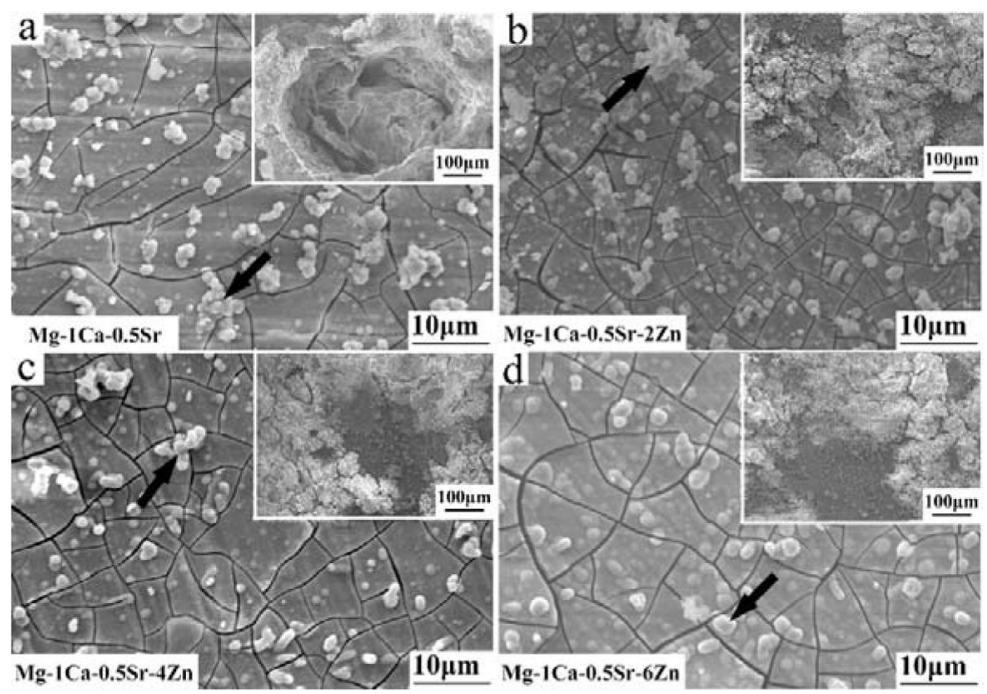

Figure 4.

Morphology of the alloys after immersed in Hank's solution for 10 days. The insets exhibited the aggregation of the corrosion products 

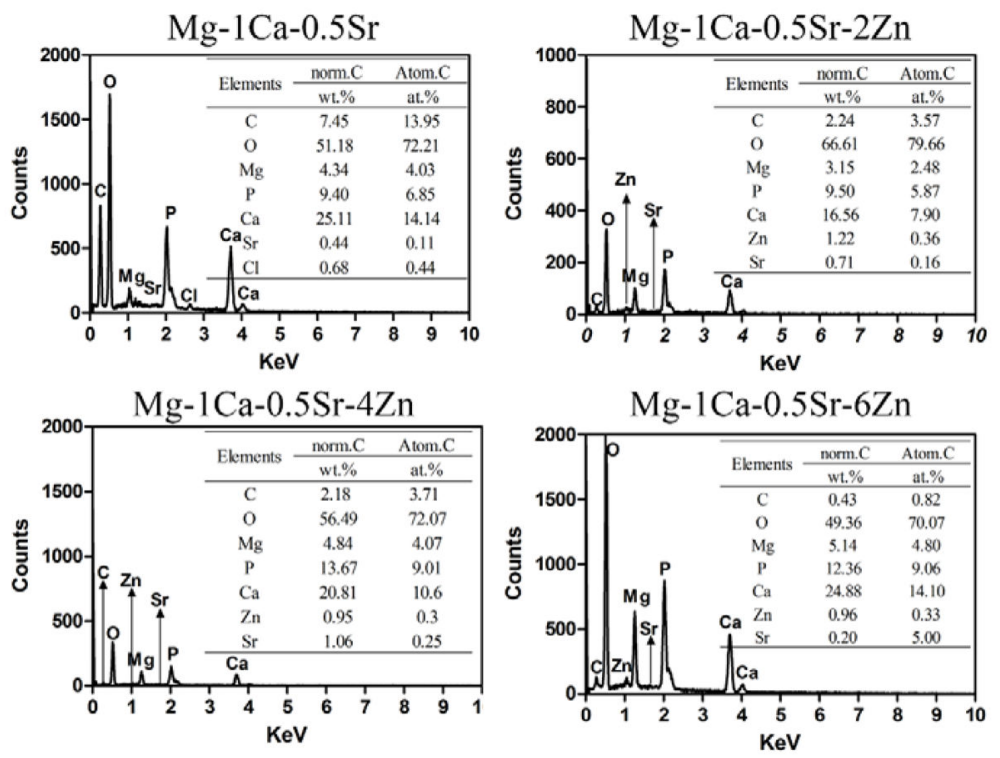

Figure 5.

EDS spectra taken from the corrosion products indicated by the black arrows in Figure 4 

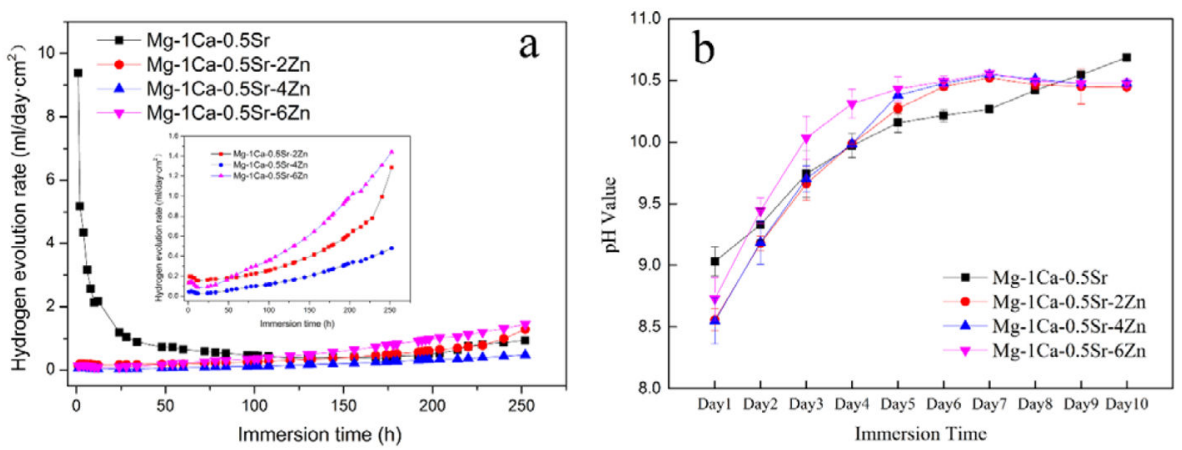

Figure 6.

Hydrogen evolution rate (a) and $\mathrm{pH}$ value of Hank's solution (b) as a function of immersion time. The inset picture in (a) depicts the hydrogen evolution rate of quaternary alloys. 


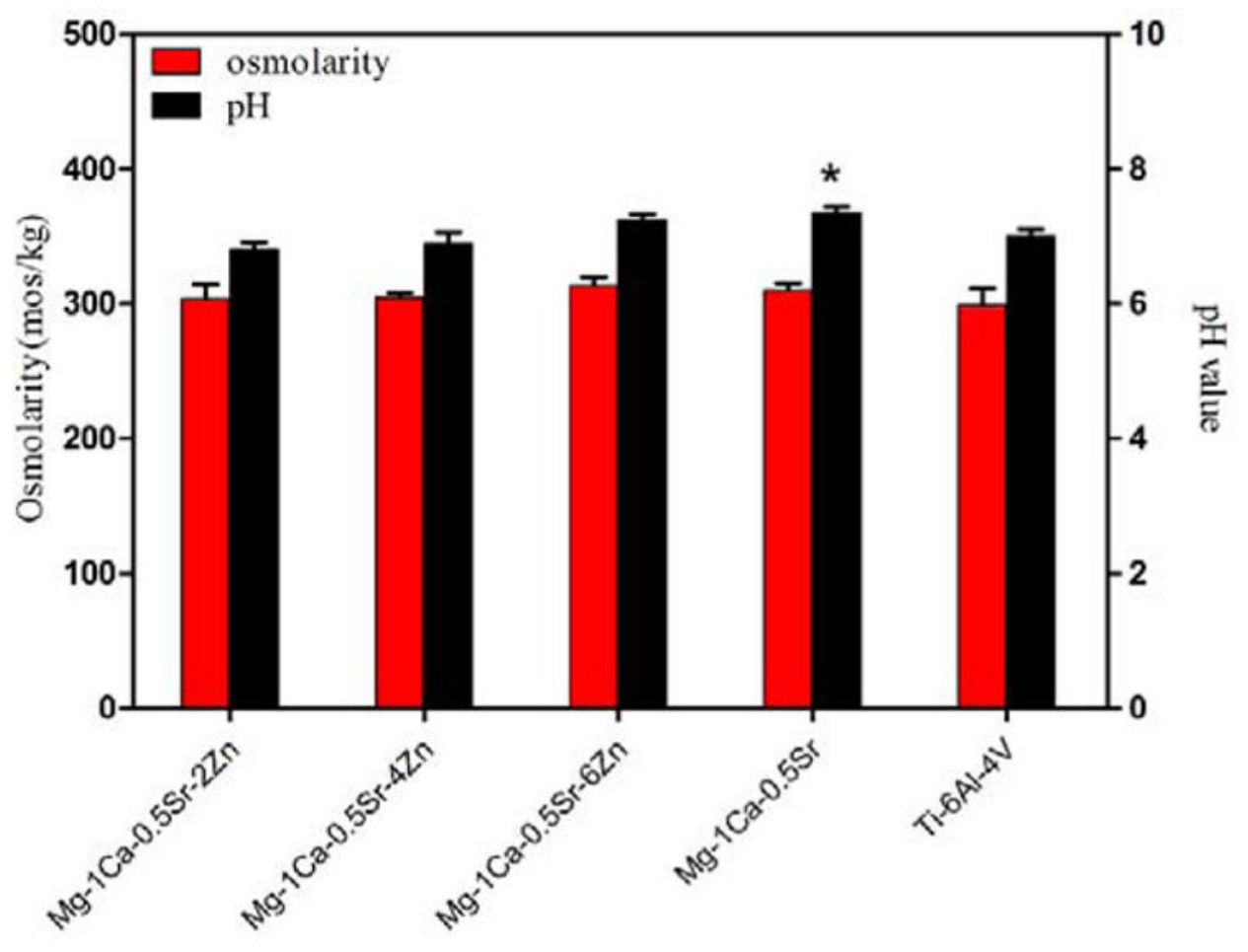

Figure 7.

Osmolarity and $\mathrm{pH}$ value of the PBS extracts of the alloys, $* \mathrm{p}<0.05$ 

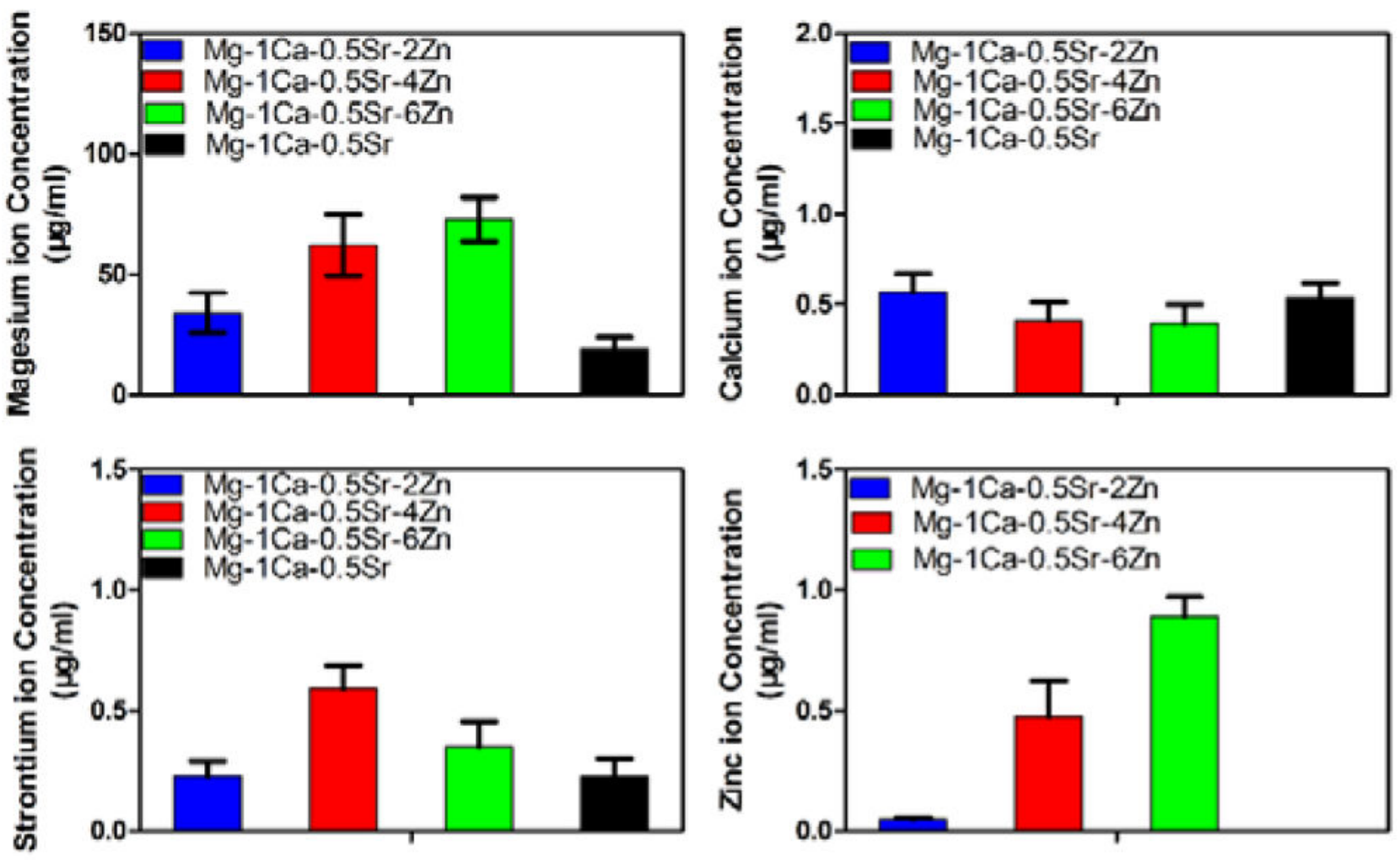

Figure 8.

Ion concentration of the PBS extracts of the alloys 

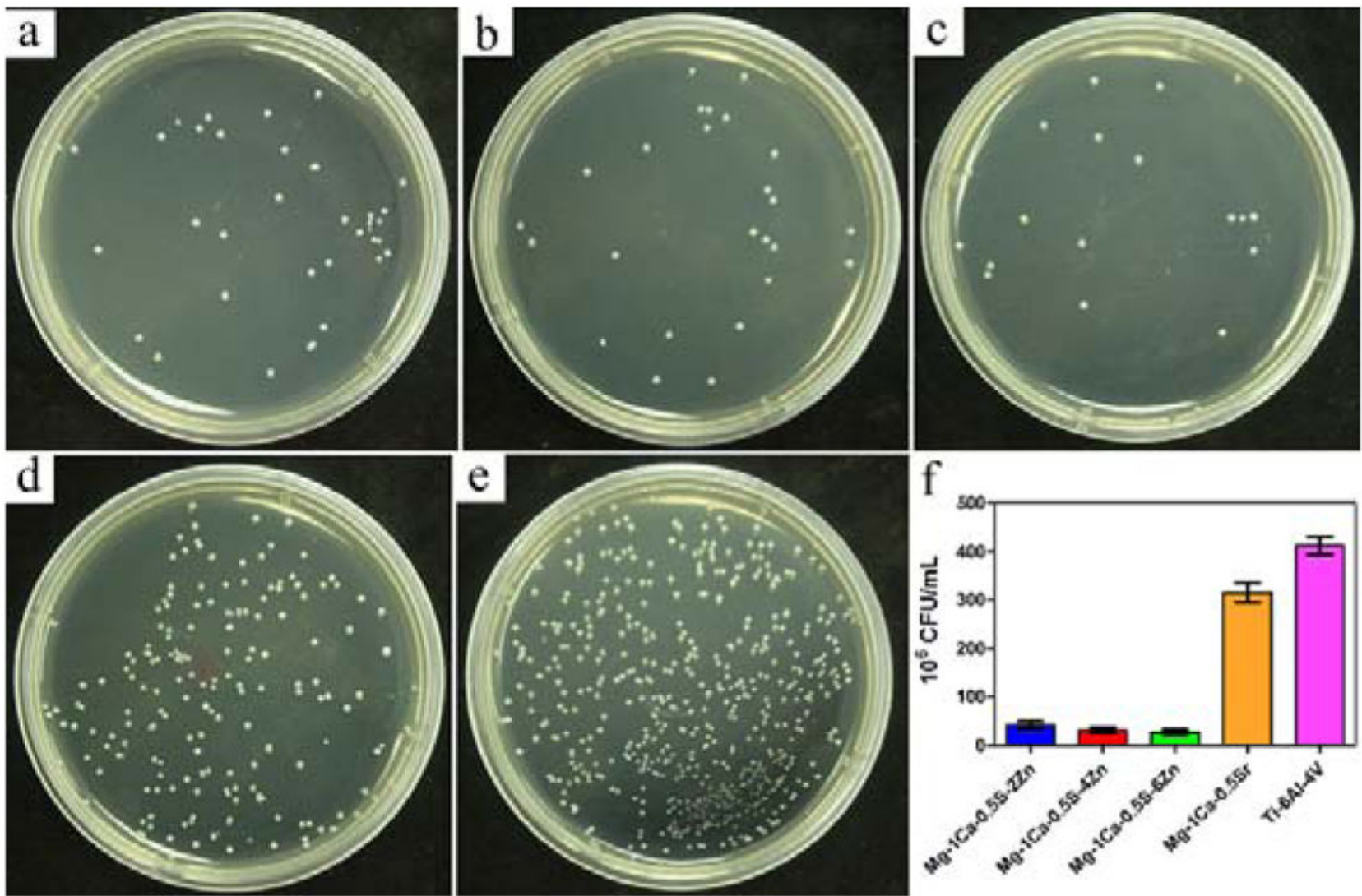

Figure 9.

S. aureus colonies after incubation with different PBS extracts of the alloys for $24 \mathrm{~h}:$ a) $\mathrm{Mg}-1 \mathrm{Ca}-0.5 \mathrm{Sr}-2 \mathrm{Zn}, \mathrm{b}) \mathrm{Mg}-1 \mathrm{Ca}-0.5 \mathrm{Sr}-4 \mathrm{Zn}, \mathrm{c}) \mathrm{Mg}-1 \mathrm{Ca}-0.5 \mathrm{Sr}-6 \mathrm{Zn}, \mathrm{d}) \mathrm{Mg}-1 \mathrm{Ca}-0.5 \mathrm{Sr}$, e) Ti-6Al-4V, f) CFU of the sample alloys. The error bars represent the standard deviations calculated from three independent experiments 


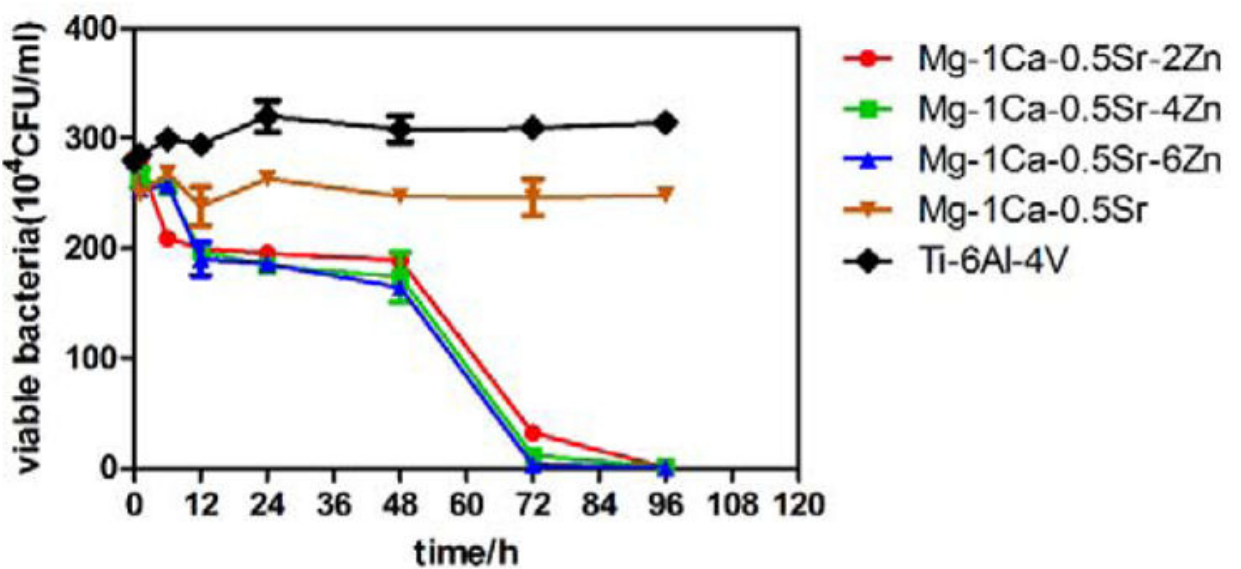

Figure 10.

Antibacterial curves of the alloys extracts extracted at different times 

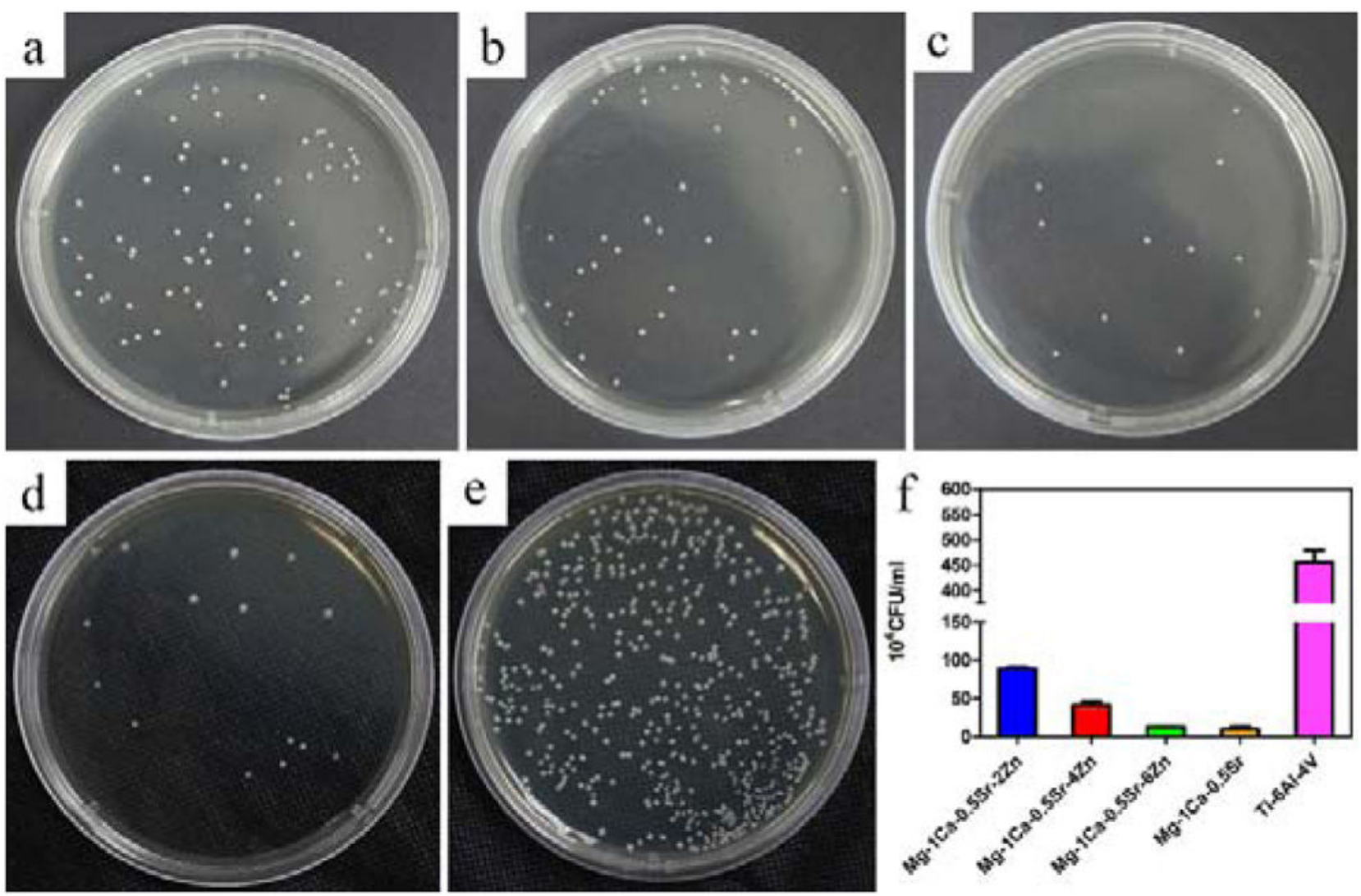

Figure 11.

$S$. aureus colonies incubated for $24 \mathrm{~h}$ after detached from the alloys surface: a) $\mathrm{Mg}-1 \mathrm{Ca}-0.5 \mathrm{Sr}-2 \mathrm{Zn}, \mathrm{b}) \mathrm{Mg}-1 \mathrm{Ca}-0.5 \mathrm{Sr}-4 \mathrm{Zn}$, c) Mg-1Ca-0.5Sr-6Zn, d) Mg-1Ca-0.5Sr, e) Ti-6Al-4V, f) CFU of the sample alloys. The error bars represent the standard deviations calculated from three independent experiments 


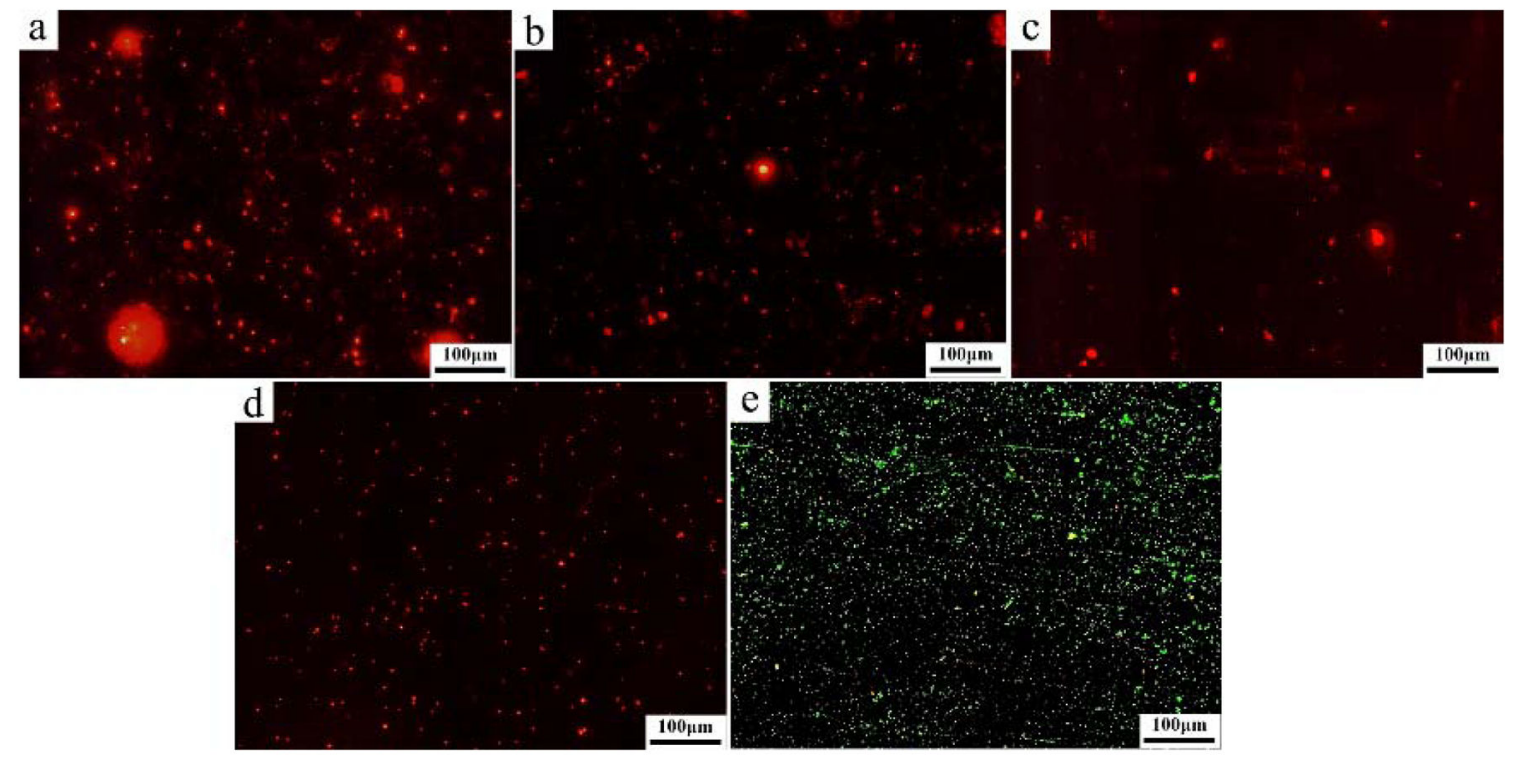

Figure 12.

Fluorescent microscopic images of $S$. aureus after $30 \mathrm{~min}$ of culturing on the sample surfaces: a) Mg-1Ca-0.5Sr-2Zn, b) Mg-1Ca-0.5Sr-4Zn, c) Mg-1Ca-0.5Sr-6Zn, d) Mg-1Ca-0.5Sr, e) Ti-6Al-4V. Live bacteria is in green and dead bacteria is in red 

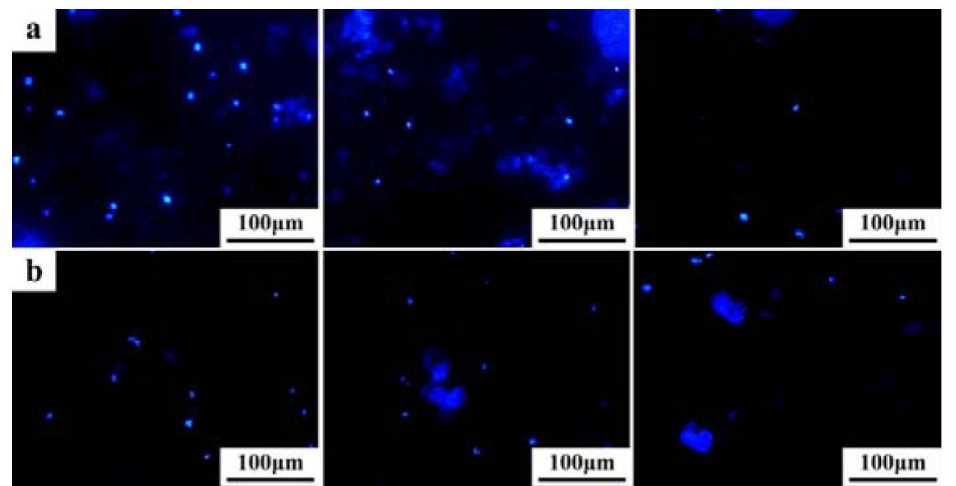

c
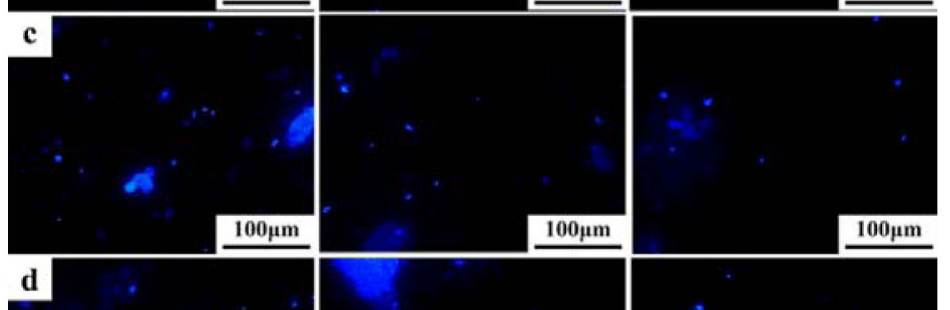

$100 \mu \mathrm{m}$

$100 \mu \mathrm{m}$

d

$100 \mu \mathrm{m}$
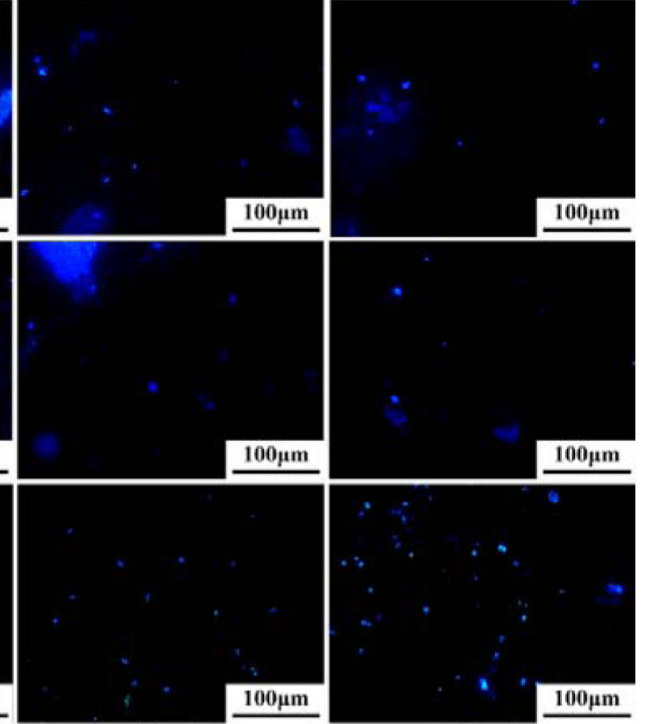

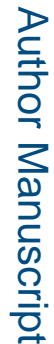

Figure 13.

DAPI staining of the adhered bacteria on the alloys surface after exposure to $S$. aureus suspension ( $\left.10^{7} \mathrm{cfu} / \mathrm{ml}\right)$ for $30 \mathrm{~min}, 60 \mathrm{~min}$ and $90 \mathrm{~min}$ : a) $\mathrm{Mg}-1 \mathrm{Ca}-0.5 \mathrm{Sr}-2 \mathrm{Zn}, \mathrm{b}$ ) Mg-1Ca-0.5Sr-4Zn, c) Mg-1Ca-0.5Sr-6Zn, d) Mg-1Ca-0.5Sr, e) Ti-6Al-4V 


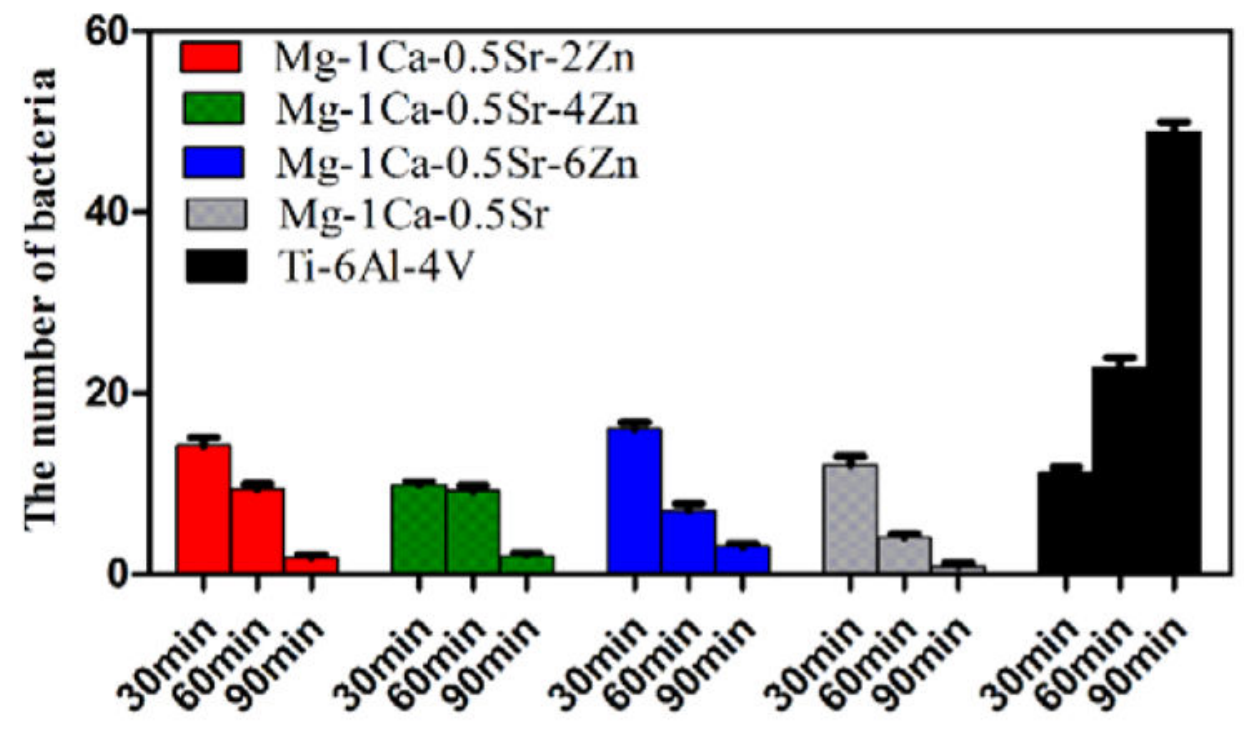

Figure 14.

The number of adhered bacteria on the alloys surfaces according to DAPI staining assay. For each alloy, five random fields were selected. 

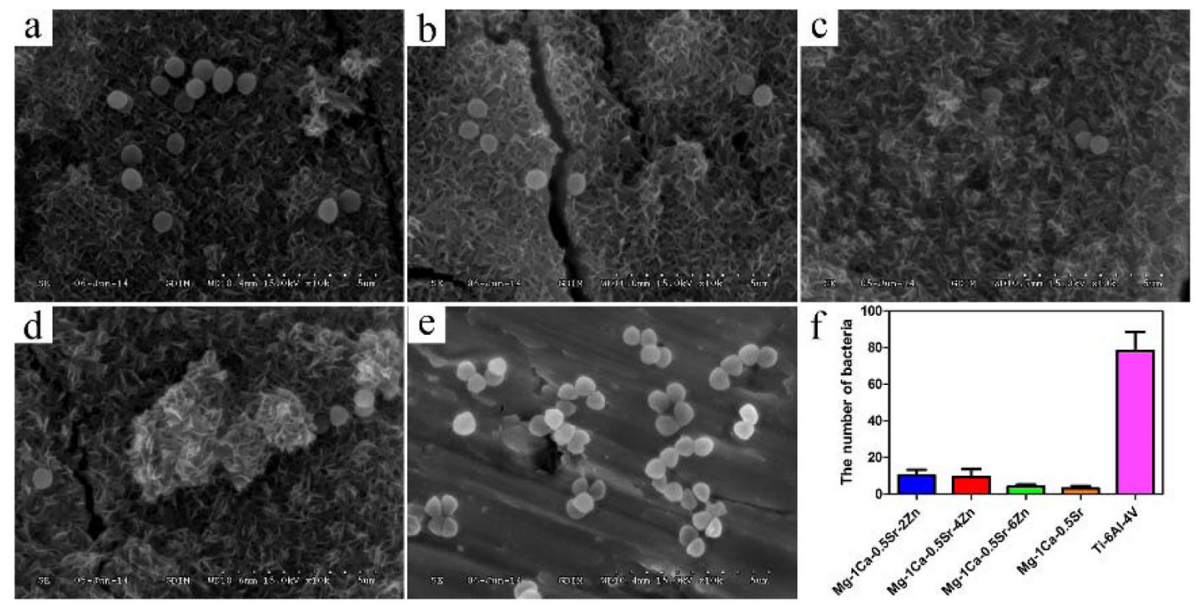

Figure 15.

SEM images of different alloys after exposure to $S$. aureus suspension for $4 \mathrm{~h}$ : a) g-1Ca-0.5Sr-2Zn, b) Mg-1Ca-0.5Sr-4Zn, c) Mg-1Ca-0.5Sr-6Zn, d) Mg-1Ca-0.5Sr, e) Ti-6Al-4V, f) the number of bacteria attached on the alloys surface. The error bars represent the standard deviations calculated from five independent experiments 


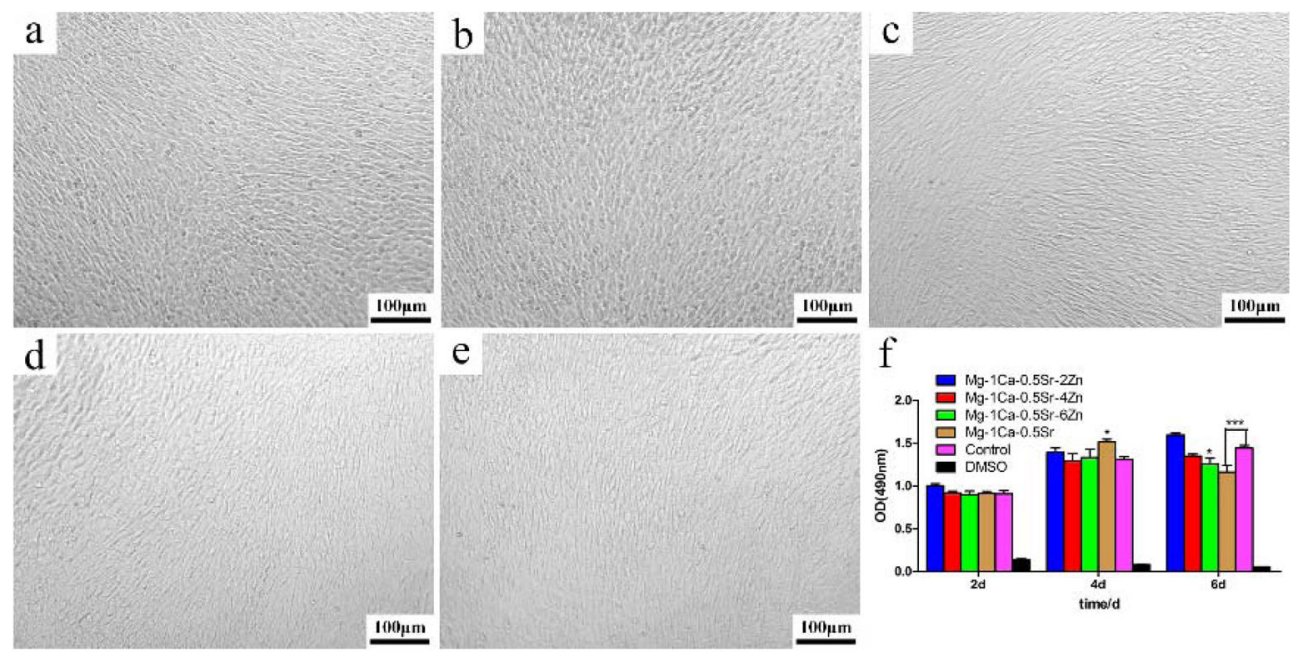

Figure 16.

Cell morphology after cultured in alloys extracts for 6 days: a) $\mathrm{Mg}-1 \mathrm{Ca}-0.5 \mathrm{Sr}-2 \mathrm{Zn}$, b) Mg-1Ca-0.5Sr-4Zn, c) Mg-1Ca-0.5Sr-6Zn, d) Mg-1Ca-0.5Sr, e) Ti-6Al-4V and f) cell viability after cultured in alloys extracts for 2, 4, and 6 days. The error bars represent the standard deviations calculated from five independent experiments 

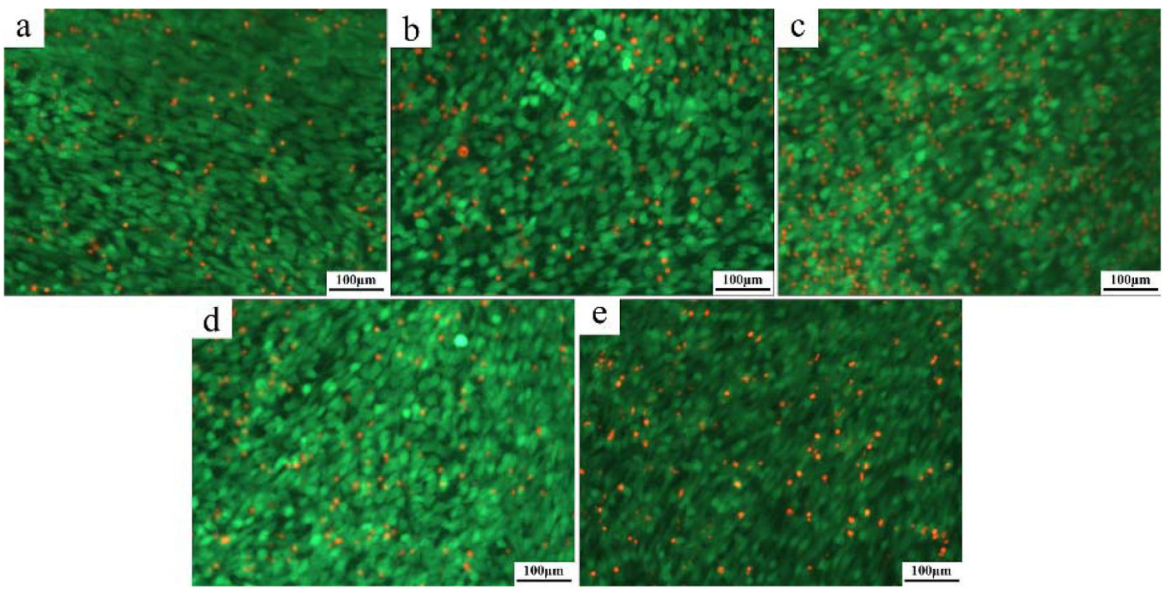

Fig. 17.

Fluorescence microscopic images of live/dead dye-stained MC3T3 cells after cultured in alloys extracts: a) $\mathrm{Mg}-1 \mathrm{Ca}-0.5 \mathrm{Sr}-2 \mathrm{Zn}$, b) $\mathrm{Mg}-1 \mathrm{Ca}-0.5 \mathrm{Sr}-4 \mathrm{Zn}$, c) $\mathrm{Mg}-1 \mathrm{Ca}-0.5 \mathrm{Sr}-6 \mathrm{Zn}, \mathrm{d}$ ) $\mathrm{Mg}-1 \mathrm{Ca}-0.5 \mathrm{Sr}$, e) Ti-6Al-4V for 6 days. Live cells are in green and dead cells are in red 